\title{
The Effects of Educational Robotics Applications on Linear Equations about Algebraic Reasoning
}

\author{
Behiye Dinçer $^{a}$ and Berna Cantürk-Günhan ${ }^{b}$ \\ ${ }^{a}$ Dokuz Eylül University, Institute of Educational Sciences, İzmir/Turkey (ORCID: 0000-0002-6452-6066) \\ ${ }^{\mathbf{b}}$ Dokuz Eylül University, Buca Education Faculty, Izmir/Turkey (ORCID: 0000-0002-9585-0811)
}

Article History: Received: 1 August 2019; Accepted: 8 August 2020; Published online: 27 August 2020

\begin{abstract}
The research aims to investigate the effectiveness of the use of educational robotics applications used in linear equations unit on seventh grade students' algebraic reasoning. Teaching experiment research design was adopted for the research. In the study, usage of idea o-bot robotics software was taught to six 7 th grade students. During the research process, three teaching experiment sessions applied after pretesting. Experiment sessions involved activities such as code writing in the face of problem situations, creating algorithms from the written code, monitoring algorithms in the simulation, and improving the algorithms when the desired result is not achieved. Lastly posttesting was performed. Comparing the pretest and posttest results, the data analyses showed that an observable development has been recorded in the algebraic reasoning skills of students' due to the fact that there are certain patterns and generalization processes in the developed algorithms. In addition, there has been an improvement in the participants' ability to use, understand and transform multiple representations in scientific process skills and problem solving skills.
\end{abstract}

Keywords: Robotics, algebraic reasoning, linear equations

DOI:10.16949/turkbilmat.600379

Öz: $\mathrm{Bu}$ çalışmada yedinci sınıf matematik dersinde doğrusal denklemler konusunda eğitsel robotik uygulamalarının öğrencilerin cebirsel akıl yürütme üzerindeki etkilerinin incelenmesi amaçlanmıştır. Araştırmada nitel araştırma yaklaşımlarından öğretim deneyi seçilmiştir. Bu çalışmada altı ortaokul öğrencisine idea o-bot robotik yazılımı öğretilmiştir. Araştırma sürecinde ön test uygulamasının ardından tasarlanan üç öğretim deneyi oturumu uygulanmış, ardından son test uygulaması yapılmıştır. Süreçte problem durumları karşısında kod yazma, yazılan koddan bir algoritma oluşturma, algoritmaları simülasyonda izleme, istenilen sonuca ulaşılamadığında yeniden algoritmasını geliștirme gibi aktiviteleri yer almıştır. Geliştirilen algoritmaların içerisinde belirli örüntü ve genelleme süreçleri bulundurması nedeniyle yapılan analizler sonucunda cebirsel akıl yürütme becerilerinde ön test ile son test karşılaştırıldığında gözlenebilir bir gelişim kaydedilmiştir. Bunun yanı sıra katılımcıların çoklu temsil biçimlerini kullanma, bu temsilleri anlama ve birbirine dönüştürme becerilerinde, bilimsel süreç becerilerinde ve problem çözme becerilerinde gelişim görülmüştür.

Anahtar Kelimeler: Robotik, cebirsel akıl yürütme, doğrusal denklemler

Türkçe sürüm için tıklayınız

\section{Introduction}

With rapid technological changes, which have an important role in shaping both the individual and society, expectations from individuals have also changed (Akgündüz et al., 2015). Among these expectations, we may encounter high-level thinking skills. Skills such as problem solving, collaboration, creativity and critical thinking that should be extant in those who have ruled society for centuries are on their way to become universal literacy in the 21st century (Akgündüz et al., 2015). These expectations can be used to define a determined, enterprising and empathic individual who does not get the information ready but interpret the given information, use it in a functional way in his/her life, think critically, solve problems, improve his/her communication skills and contribute to the society (Ministry of National Education [MoNE], 2018). Along with all these criteria, it can be said that the importance of raising individuals who do not only consume technology but also produce it increases. Various educational robotics applications have become widespread in educational environments of societies who want to produce technology-supported products in the last five years (Freeman, Adams-Becker, Cummins, Davis, \& Hall Giesinger, 2017). Many countries are doing research on educational robots worldwide, and among these, countries such as Japan, Canada, New Zealand, South Korea, Australia, Taiwan, the United States and Portugal are the leading ones. Institutions such as The Japan Robotic Association (JARA), the International Federation of Robotic (IFR) and the United Nations Economic Commission (UNEC) report that in recent years robots have grown significantly in the field of education and in parallel, so does their market share and they will continue to grow even more rapidly over the next decade (Barreto \& Benitti, 2012).

Corresponding Author: Behiye Dinçer iD email: behiyedincer@gmail.com

* This study was produced from the first author's Master's thesis under the supervision of the second author, and supported by Dokuz Eylül University Scientific Research Projects Coordinator with the project number 2018.KB.EGT.003.

Citation Information: Dinçer, B. \& Cantürk-Günhan, B. (2020). The effects of educational robotics applications on linear equations about algebraic reasoning. Turkish Journal of Computer and Mathematics Education, 11(2), $492-527$. 
It is known that robotic activities, competitions and studies draw interest in Turkey (Aksu, 2019; Göksoy \& Y1lmaz, 2018; Kıran, 2018; Zengin, 2016). However, studies on robots in the world and in our country were generally carried out within the scope of the courses, clubs and projects (Çavaş \& Huyugüzel-Çavaş, 2005; Gennari, Dodero \& Janes, 2012; Koç-Şenol \& Büyük, 2015; Şişman \& Küçük, 2018; Witherspoon, Reynolds, Copas, \& Alagic, 2004). In our country, mostly in private schools but also in some public schools with the personal efforts by the teachers of information technology courses or in the club activities educational robotics applications are made. In addition many universities started to launch robotic summer camps (Şişman \& Küçük, 2018). Educational robotics applications contribute to creating a positive opinion on interdisciplinary studies (Zengin, 2016) and an effective learning environment (Şişman \& Küçük, 2018). One of the unique features of this research is that robotic applications are associated with mathematics course acquisitions beyond the use of club activities, robotic competitions, and it is used as a course application tool in teaching by code writing in case of a problem situation. It is also thought that it will contribute to the development of algebraic reasoning, which is one of the special areas of mathematical understanding. Therefore, in the face of problem situations, it is aimed that participants make robotic coding and then observe the movements of the robot and express the situations that occur in multiple representations, thereby observing the development of algebraic reasoning.

\subsection{Robot Mathematics}

A new technology field, which has become popular in recent years, "Robotics" is the field of technology that includes the operation and use of robots, robotic modeling, design and programming processes (Silik, 2016). Robotic technology offers educators in the field of education an integrated robotic curriculum. In addition, by performing advanced technology applications on robots in the learning environment, it is used to make learning more meaningful and permanent along with providing practical and theoretical products that will facilitate the daily lives of these acquired knowledge and skills (Wood, 2003). Robotics is a visible technology branch of programming that involves programming, construction and design processes related to robots (Karsan-Erbaş, 2014). In recent years, educational robotics studies are used to support Science, Technology, Engineering and Mathematics [STEM] education, in order to gain basic knowledge and skills (Üçgül, 2013). When the curriculum of the STEM courses are examined, it is revealed that the students developed using critical thinking, questioning skills and problem solving robotic activities (Board of Education and Discipline [BED], 2006a, 2006b, 2009). Robotic applications seem to contribute to the development of students' problem solving skills (Eguchi, 2010; Gerecke \& Wagner, 2007; Goldman, Eguchi, \& Sklar, 2004; Göksoy \& Y1lmaz, 2018; Ribeiro, 2006; Silik, 2016), critical thinking skills (Eguchi, 2010; Jimoyiannis \& Komis, 2001; Gerecke \& Wagner, 2007; Ribeiro, 2006; Silik, 2016), the levels of using technology (Silik, 2016; Ribeiro, 2006) and creative thinking skills (Eguchi, 2010; Gerecke \& Wagner, 2007; Göksoy \& Yılmaz, 2018; Jimoyiannis \& Komis, 2001; Lin et al., 2009). Indeed, many studies show that robotic activities have many positive effects on STEM education (Alimisis, 2013; Barreto \& Benitti, 2012; Bruciati, 2004; Eguchi, 2010; Küçük \& Şişman, 2017; Liu, Lin, Feng, \& Hou, 2013; Gerecke \& Wagner, 2007).

Çavaş and Huyugüzel-Çavaş (2005) states that learning by doing-living and designing in a fun way maximizes learning and also increases the permanence of learning. When we look at the studies on the use of robotics in education in the world, it is clear that robotics provides an important and enriched learning environment for students (Koç-Şenol \& Büyük, 2015). In this context, for the education of the individual described among the aims of today's contemporary education, the permanence of learning by doing-living in such enriched learning environments can be increased.

Papert (1972) also emphasizes that students can learn best when they participate actively to the process and create meaningful products. In educational robotics applications that develop over time, students take an active role in every stage of the learning process (Alfieri, Higashi, Shoop, \& Schunn, 2015). In this process, students design and programrobots, and see the results instantly. By doing so, students make assumptions, test these assumptions, verify them, re-assume them if they cannot verify, and solve the problem at the end of the process. In addition, while students program their robots with block-based or text-based visual programming tools, they also interact with the environment by using various sensors such as infrared, touch, color and sound. Thus, students can develop unique robotic projects that can perform different functions in line with the goals they set. Studies in the literature have shown that educational robotics applications are also effective in developing students' scientific process skills (Koç-Şenol \& Büyük, 2015; Eguchi, 2010; Lin et al., 2009; Gerecke \& Wagner, 2007). Papert (1993) believes that coding activities have enormous potential to improve classroom teaching. However, Williams, Ma, Prejean, Lai, and Ford (2007) confirm that there is limited empirical evidence to prove the effect of robotic applications on the K-12 curriculum. Educators have started generating ideas and developing activities to incorporate robotics into the teaching of various subjects, including mathematics, science and engineering. On the other hand, Johnson (2003) states that there is no research directly supporting the impact of robotics on the students' academic performance and robotic activities might just be a "fashionable" subject. Researchers emphasize that most of the literature on use of robotics in education is descriptive, based on the 
reports of teachers who have achieved positive results with individual initiatives (Williams et al., 2007; Caci, Cardaci, \& Lund, 2003).

Robot mathematics, an interdisciplinary combination of technology, engineering and mathematics, highlights the significance of interdisciplinary perspective for students and why these disciplines make each other necessary and how they facilitate each other (Alfieri et al., 2015). Researchers focus on the possible use of robotics lessons in reinforcing students' understanding of mathematical concepts (Barreto \& Benetti, 2012; Vollstedt, Robinson, \& Wang, 2007 by Dinçer-Kucuş \& Cantürk-Günhan, 2017, p. 621). Robotic-mathematics is a term used to describe mathematics teaching focusing especially on robotics (Dinçer-Kucuş \& Cantürk-Günhan, 2017). In the robotic coding process, students canencounter mathematical problems in a concrete context while coding for the problem situation. Facing mathematical problems in different contents can give the student both experience and self-confidence in the context of robot mathematics. Accordingly, it can be predicted that the student will have the ability to understand and sense the mathematical concepts more quickly. Making sense of mathematical concepts brings the student closer to learning. For this reason, examining how students reflect their mathematical skills in robotic mathematics can be useful. In this study, it is aimed to examine students' algebraic reasoning skills.

\subsection{Algebraic Reasoning Skills}

Reasoning is the process of thinking and achieving a rational conclusion by considering all the factors (Kaya $\&$ Keşan, 2014). Those who can reason on a subject have a sufficient level of knowledge about that subject and can examine a situation that they have encountered with in all aspects to make reasonable predictions and assumptions, then explain and defend the conclusions they reached (Umay, 2003). Reasoning can be expressed briefly as thinking logically, making judgments and inference. As Çelik (2007) stated, reasoning has an important place in preparing individuals for life as well as preparing them for future academic and business life. Reasoning is an important skill that facilitates life, as reasoning and making effective decisions are made thanks to reasoning (Erdem, 2011). Mathematical reasoning involves exploration with emerging mathematical ideas along with structuring, explaining, interpreting and approving the problem when individuals seek answers to the question (Kasmer, 2008). Algebraic reasoning is a component of mathematical reasoning (Nilklad, 2004). It is a way of thinking that includes vital skills for mathematics such as reasoning, using representations, explaining the meaning of symbolic representations, understanding variables, converting between representations, problem solving and working with models for the development of mathematical ideas (Kaf, 2007). Therefore, algebraic reasoning can be said to be a prominent concept in mathematics teaching at all grade levels. In addition to this, algebraic reasoning skill includes activities not only within the scope of mathematics lesson but also of thinking, interpreting and searching for solutions to the difficulties that individuals face in daily life (Bike-Kalkan, 2014). These activities are thought to affect mental processes such as thinking, interpretation, and solution seeking. Perhaps these activities can improve students' reasoning skills by using appropriate teaching methods and techniques in the classroom setting.

Algebraic reasoning involves expressing information in different representation forms such as words, tables, graphs and equations in case of a problem; meaningful use of mathematical structures, symbols, tools and operations; It is a form of reasoning that includes formulating patterns, creating equations, understanding functions and relations, and inductive and deductive thinking (Driscoll, 1999; Greenes \& Findell, 1998; Herbert \& Brown, 1997; Kaput, 1999; Kieran \& Chalouh, 1993; NCTM, 2000). Thus algebraic reasoning is defined as a type of reasoning that covers abstractions through generalization of variables, transformation of representation forms and calculations (Vance, 1998). Considering all these definitions, it can be said that the development of algebraic reasoning skill in the individual is very important. Indicators for algebraic reasoning skills are reflected in Table 1. These indicators have been developed by Kasmer (2008) by adopting the expectations of the cognitive domain of NCTM and TIMMS (as cited in Bike-Kalkan, 2014, p.14). It was also translated into Turkish in the study of Bike Kalkan (2014) and they are mentioned as "algebraic reasoning indicators".

The reason why the conceptual framework mentioned above is preferred in this study is that it contains systematic indicators, the representation power of the literature, and its aid to observe the gains expressed in the 2017-2018 academic year curriculum. In addition, despite individuals can reflect most of the above indicators individually, if the R5 and R6 indicators are taken into consideration, this is not the case because these indicators include expressions such as "making sense of others' thoughts / ideas / approaches" and "asking questions and increasing discussion". That is why this study also included group studies. 
Table 1. Algebraic Reasoning (R) Indicators

\begin{tabular}{ll}
\hline Indicator & Explanation of Indicators \\
\hline $\mathrm{R}(1):$ & Formulate, evaluate and support generalizations: \\
& To be able to make a statement about something right for any situation. \\
$\mathrm{R}(2):$ & Create, evaluate and support mathematical arguments: \\
& It is the ability to make an informal or formal statement about a particular or general \\
& situation, that is, to make an assumption for the final generalization. \\
$\mathrm{R}(3):$ & Analyze and evaluate the problem situation: \\
& To be able to reveal useful information from the problem for the solution. \\
$\mathrm{R}(4):$ & Use inductive and deductive reasoning to establish or support mathematical relationships: \\
& Using inductive reasoning, looking for mathematical relationships in pattern studies, and \\
& using deductive reasoning, using a mathematical relationship established to support a pattern \\
& in a particular situation.
\end{tabular}

$\mathrm{R}(5)$ : $\quad$ Make sense of others' thinking / ideas / approaches and provide rationale behind them: To be able to understand whether the logic and reasoning of others can be accepted with a critical / evaluative approach.

$\mathrm{R}(6)$ Ask questions and raise challenges in situations of misunderstanding or disagreement: Asking for clarification or being able to provide an opposing view.

$\mathrm{R}(7)$ Draw and support conclusions in varied topics:

To be able to make a statement summarizing the findings without having to generalize or make an argument.

In this study, it can be said that the reason for considering coding and linear equation together is that algebraic reasoning processes and coding processes contain similar ways. Coding is the process of determining how to create a solution by linking the patterns step by step in a problem to be solved (Üzümcü \& Erdal, 2018). Thus, in the development of twenty-first century skills, a new orientation can be added to the field of technology-supported mathematics education capable of producing technology. At this point, the aim of this study is to create a mathematical learning environment with middle school students who know the idea o-bot robotics software and to examine the development process of algebraic reasoning in linear equations in algebra sub-learning. The research problem is determined as follows: "How is the development of algebraic reasoning on linear equations of 7 th grade students with a teaching experiment method designed by utilising educational robotics applications?" The sub-problems of this problem are as follows:

- "What is the algebraic reasoning development of 7th grade students about linear equations before educational robotic applications?"

- "How is the development of algebraic reasoning on linear equations of 7th grade students during the teaching experiment of educational robotics applications?"

- "How is the development of algebraic reasoning of 7th grade students about linear equations after educational robotic applications?"

\section{Method}

Qualitative research methods have been preferred in this research, since it is aimed to investigate the development of algebraic reasoning skills of seventh grade students in linear equations with educational robotic applications. Because qualitative research methods aim to question the behavior of the research sample in its natural environment, it enables the researchers to reach in-depth information on the research subject (Lempp \& Kingsley, 2007). In this study, teaching experiment pattern is used as a qualitative approach. Teaching experiment is an effective method that can be utilised to understand students' mathematical facts and to reveal the behavior patterns in this process (Lesh \& Kelly, 2000; Steffe, 1991; Steffe \& Thompson, 2000). In this study, the teaching experiment method is used to make sense of how algebraic reasoning develops based on the knowledge of the linear equations in the mind of the students and the ability to use the idea o-bot before the research process.

\subsection{Participants}

In this study, participants were selected through criterion sampling method of purposeful sampling. Purposeful sampling is selected for the purpose of interpreting, explaining and making an in-depth analysis of situations and events that are thought to provide rich data. (Yıldırım \& Şimşek, 2005). In criterion sampling, the situations that meet the specified criterion or criteria are studied and these criteria can be taken from a precreated list or prepared by the researcher (Yıldırım \& Şimşek, 2005). The participants in this study are 7th grade 
students in a middle school located in the central district of Muğla province. In the study, four basic criteria were taken into consideration in the selection of 6 students. These criteria are as follows:

- students should know about basics of coding,

- the success of students in mathematics course is medium or high,

- students should be able to express themselves well,

- students are volunteers to participate in study.

While determining the participants, the ideas of mathematics teachers and informatics teachers were taken. Nicknames were used in the study. The features of the participants are given in Table 2.

Table 2. Participants' Features

\begin{tabular}{cccc}
\hline Nickname & Academic success & Self-expression skill & Knowledge of other programs \\
\hline Ilgaz & High & Good & He does not know \\
Eren & Medium & Good & He does not know \\
Su & High & Good & She does not know \\
Mert & Medium & Good & He knows \\
Asya & Medium & Good & She does not know \\
Emre & High & Good & He knows \\
\hline
\end{tabular}

In the study, groups of two people were formed, one with medium and one with high the academic success and in these groups, a learning environment was created to support each other in the zone of proximal development of the participants.

\subsection{Data Collection Tools}

In the research, pre-test, tasks in the teaching experiment process and post-test were used as data collection tools. Developed in line with the algebraic reasoning indicators, the pre-test was prepared considering the teaching program outcomes while preparing the teaching experiment tasks and the post-test. Then, the opinions of one mathematics educator and two experienced mathematics teachers regarding the suitability of the reasoning indicators of the tools to be used in the whole process were taken. In the pre-test, 7 questions were asked to the participants. The teaching experiment consists of three sessions, and in each session, tasks were assigned under a scenario. In the first session, the questions asked in line with the scenarios and tasks developed within the $\mathrm{y}=\mathrm{ax}$ equation in the second session and the $y=a x+b$ equation in the second session was tried to be measured. The third session was prepared upon the observation of R5 and R6 indicators only during group work. In the post-test, 6 questions were asked to the participants. In Table 3, the expectations from participants and the indicators of the questions are given in the content section of these data collection tools.

Table 3. Questions, indicators and expectations

\begin{tabular}{|c|c|c|c|}
\hline & Data Collection Tool & Content of the Problem & Indicator \\
\hline \multirow[t]{2}{*}{ Pre-test } & $\begin{array}{l}\text { A } \\
\text { The seats of an ancient theater } \\
\text { are divided into three sections, } \\
\text { namely A, B and C from the } \\
\text { bottom up. In the sections } \\
\text { named as A and C, the seats } \\
\text { increase from bottom to top, } \\
\text { and in the section named as B, } \\
\text { they increase by two. Regarding } \\
\text { the linear increase in the } \\
\text { number of seats in the ancient } \\
\text { theater; }\end{array}$ & $\begin{array}{l}\text { It is expected to write a number pattern and a } \\
\text { table for this situation. } \\
\text { The generalization of this situation is expected } \\
\text { to write the verbal expression and linear } \\
\text { equation. } \\
\text { It is expected to calculate how many viewers } \\
\text { will sit on the seats in the desired section. } \\
\text { It is expected to graph the linear equation of } \\
\text { the situation to occur. } \\
\text { When there is a change in the statements given } \\
\text { at the root of the initial question, the change in } \\
\text { the number of people who can sit in the } \\
\text { equation and the seats is expected to be } \\
\text { explained. }\end{array}$ & $\begin{array}{c}\mathrm{R} 4 \\
\mathrm{R} 2 \\
\mathrm{R} 1-2-3-4-7\end{array}$ \\
\hline & $\begin{array}{l}\text { B } \\
\text { Regarding the time-dependent } \\
\text { graph of the path followed by } \\
\text { the ball during the match in a } \\
\text { sports with the ball; }\end{array}$ & $\begin{array}{l}\text { It is expected that the ball will be able to } \\
\text { interpret the time dependent graph of the path } \\
\text { followed during the match. } \\
\text { Similarly, it is expected to draw a time- } \\
\text { dependent change graph for another sport. }\end{array}$ & R 3 \\
\hline
\end{tabular}


Table 3 continued

In a ten-story car park using a It is expected that the algorithm that will be car park guidance system, the required in this process will form the coding

R 1-2-3-4robot required to park a car in an empty space;

with the group friend.

It is expected to write a number pattern and a table for this situation.

The generalization of this situation is expected to be written in the verbal expression and the linear equation in $y=a x$ format.

\section{Teaching experiment 1}

There is a fireplace in a room and a sensor $20 \mathrm{~cm}$ away from the fireplace. About writing a code that will give a warning when the sensor is approached more than $20 \mathrm{~cm}$ while the

Teaching experiment 2

It is expected that the robot can explain where it will be in the desired second.

Time dependent graph of the path of the robot is expected to be drawn.

If there is no car parking guidance system, it is expected to create an assumption about the situation in this car park and explain how the equation of this situation will be.

She/he is expected to write a code that will provide this situation with her group friend.

R 1-2-4-7

R 1-2-3-4-7 The student is expected to write the table and the equation in the format $y=a x+b$ in the time desired for a baby to approach the fireplace from the point where baby is located, taking into account the path baby has taken in minutes.

The student is expected to write the equation of departure from the wall in the format $y=a x+$ $b$ by interpreting the opposite of the same situation.

The student is expected to explain the variation of the time-dependent linear equation of the location of the sensor in the room and the path the baby takes in the event that the infant's crawling rate increases.

\begin{tabular}{cl}
\hline & They are expected to create \\
Teaching & choreography for 10 seconds \\
experiment & with 3 robots. \\
$\mathbf{3}$ &
\end{tabular}

It is expected that the table of the ten seconds process will be created as the path taken per second and plotted with the help of sequential binaries.

The linear equation of the preferred seconds intervals is expected to be written.

A graph of the performance of It is expected that a table of the number of R 1-2-3-4$5-6-7$

R 2-3 plates prepared by Chef A and Chef B based two chefs (A and B) who on time will be created and sequential pairs applied for a job to be will be written. employed in their kitchen is The student is expected to comment on the given. For this; number of plates that two cooks can prepare within the specified time.

The student is expected to write the generalization and verbal expression of the situation between two chefs preparation time $(\mathrm{t})$ and the number of plates prepared (p).

The student is expected to explain the employer by justifying whom to hire at the end of the trial period.

B

Regarding the time-dependent graph of the path followed by the ball during the match in a sports with the ball;
It is expected that the ball will be able to interpret the time dependent graph of the path followed during the match.

Similarly, it is expected to draw a timedependent change graph for another sport.

\section{R 1-2-3-4- \\ $5-6-7$}

R 1-3-4

R 2-3

R 4

R 1-2-4-7

R 7 
During the teaching experiment process, while answering the pre-test and post-test questions, the whole process was recorded with the permission of the participants. The findings from these records and from the papers on which the students wrote their answers were also reflected in the research.

\subsection{Data Analysis}

The analysis of the data obtained from the teaching experiment is carried out in two ways, namely retrospective and prospective analysis. Prospective analysis is that the researcher constantly analyzes applications in the process, as a result of which it presents alternative learning ways to improve teaching and learning (Cobb, Confrey, Disessa, Lehrer, \& Schauble, 2003). Retrospective analysis is the demonstration that the model put forward is reliable and consistent by analyzing the data at the end of the study (Cobb, 2000; Cobb et al., 2003; Steffe \& Thompson, 2000). In this study, in the analysis of the teaching experiment process, prospective analyses were made after each application, and the following application was continued in the light of these analyses. In the light of the indicators in Table 1, in the pre-test, teaching experiment process and posttest, students' situations were analyzed with content analysis by creating themes such as "formulating and supporting generalizations, constructing mathematical arguments, analyzing problem situation, establishing mathematical relationships, verifying conclusions in varied topics". In these themes, the reflections on the students' reasoning indicators are exemplified as shown below based on the "formulating and supporting generalizations" theme;

True: The student was able to write the linear equation correctly.

Partially True: The student was able to write the linear equation partially.

Wrong: The student has written the linear equation incorrectly.

Empty: The student left the question blank.

Furthermore, in order to understand whether the questions are understood or not, a pilot application was made with two students studying in 7th grade and reorganization was made to make the items in the tests and teaching activities more clear and understandable. In ensuring the validity of the research; literature and expert opinions were taken into consideration while developing data collection tools. Voice recordings were transcribed and checked by researchers. The codings obtained from the data were made by the researchers at 6-month intervals, and the percentage of compliance between these two analyzes was calculated as 95\%. Furthermore, at the end of the session, participants were asked questions such as "What did you think here?", "Can I ask the reason for writing this statement here?" about their answers to open-ended questions. The results obtained were constantly compared, thereby ensuring confirmation. For transferability, direct quotations from the statements of the participants are included.

\subsection{Implementation Process}

A pilot implementation of the teaching experiment was carried out before the main implementation of the research. In pilot practice, the teaching experiment took place in two sessions, and when the process was analyzed, it was noticed that the algebraic reasoning indicators R5 and R6 which are expected to be observed in the students were not observed sufficiently. For this reason, a third teaching experiment session was designed, expert opinion was taken and applied. This pilot implementation was completed two weeks before the main implementation. The teaching experiment with the main working group was carried out in three sessions. Teaching experiments were carried out one week apart. The implementation process of this research took five weeks with pre-test and post-test. The diagram describing the implementation process is displayedin Figure 1.

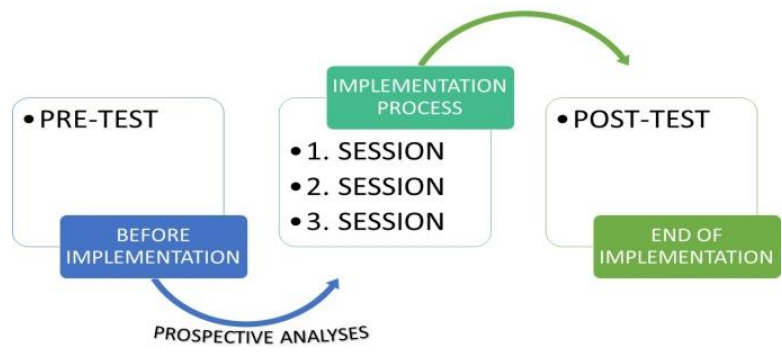

Figure 1. Implementation Scheme

In the first session, the scenario stated in Table 3 was given and the participants were asked to write the algorithm of the movements of the idea o-bot that would act according to this scenario from three groups (Group1: Ilgaz-Eren, Group2: Su-Mert, Group3: Asya-Emre). After the processes of writing the codes were completed, questions were asked through the scenario and students were asked to answer individually. In the second session, a new scenario was given and according to this scenario, it was requested from the same groups to write an algorithm that will detect the motion and temperature of the idea o-bot's sensors. The groups, such as 
the process in the first session, answered the questions individually after writing the algorithm together. In this session, while discussing about the new algorithm and equation that will occur when some of the variables in the scenario are changed, it was observed that there was an uncertainty in the minds of the participants. While this uncertainty was independent of the variables of the algorithm and equation, the change in the scenario affects the variables of both states in different ways. For this reason, before proceeding to individual responses in the second session, a discussion was held on the concept of variable. In the third session, participants were expected to create choreography together to dance their robots, reflect this choreography to the algorithm, and then transform the robot's movements into equations and other representational forms as a result of the algorithm. Each session lasted about an hour.

\section{Findings}

In the pretest, the arrangement of the seats in an ancient theater was given and it was asked to calculate the number pattern, table, graphic, verbal generalization sentence, linear equation and how many seats were in a certain order. Also, they were asked to guess what sport could be played over the height of the ball in the process on a given graph and to draw a graph for the height of the ball from the ground for a sport branch they love. In this section, the findings of the participants were examined in the form of themes in line with the answers given in the pretest. These themes are "formulating generalizations, creating mathematical arguments, analyzing problem status, establishing mathematical relations, verifying the results on various topics".

In the test, the first question was as follows: "In an ancient theater, the seats consist of three sections and there are 10 seats in the $A$ and $C$ sections, and the number of seats increases by 1 in each row. In section $B$, there are 20 seats in the first row and the number of seats increases by 2 each row. If the number of seats increased by two in each column, what would the linear equation be?" Su responded to the question as " $(8+2 x)$ .3" reaching to the generalization for the A and C rows with ten seats in the first row, but not for the B row with twenty seats. Therefore, it can be said that it showed partial success in formulating generalizations in pretesting. Ilgaz said, "There would be no change in B because there are already two in B". This interpretation of Ilgaz is an indication that it can produce an informal mathematical argument. Asya, in her paper, made informal statements during the induction process: "There are two seats in $A$ and $C$, while $B$ increases in two seats." and "There would be a total of four increases in $A$ and $C$ in the new case, $B$ wouldn't change." It is seen that Asya can establish a mathematical relationship between her data in her responses. From the point of view of verifying the results on various issues, it is seen that Emre's answer in a question asked supports and confirms both with linear equation and verbal generalization as seen in Figure 2.

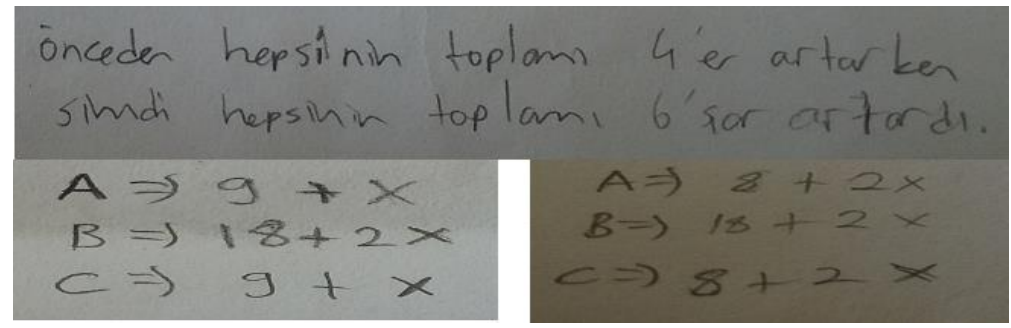

Figure 2. Example of Verifying Emre's Results

It is seen in Figure 2 that Emre, one of the participants, delivered the correct answer based on the graph given in the question during the problem solving process. While solving the problem, it was observed that he draws the road graph based on time correctly in accordance with the sports that he wasinterested in.In the theme of analyzing the problem situation, it can be said that Emre can reveal useful information from the problem and is sufficient in this respect.
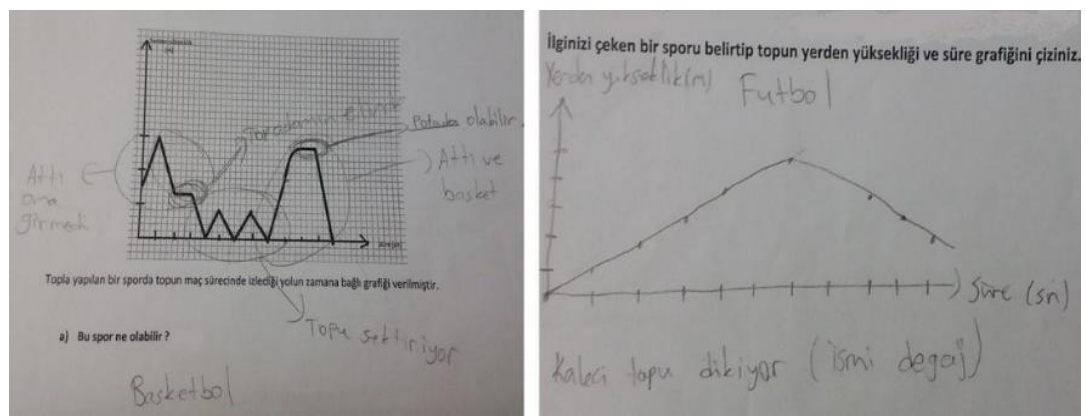

Figure 3. Emre's Graphic Interpretation and Drawing 
To analyse the pretest analysis in general, when the theme of supporting generalizations is considered, the representation of the table was used by all participants, and representation and support with the number patterns were seen in the responses of the three participants. It was seen that four participants could reach verbal generalization, but the participants had difficulties in establishing a linear equation in $y=a x$ or $y=a x+b$ format in general. In the process of creating an argument, formal explanation was made only by one participant, and in the informal explanation direction of the general trend, it was observed in half of the participants. While analyzing the problem situation, all participants benefited from the table, while it was seen that one participant benefited from the graphic and the equation while there was half of the participants benefited from the pattern. When looking at the theme of building a mathematical relationship, it is important that both inductive and deductive explanations are informal. The answer in the theme of verifying the results on various topics, which is the last theme, is very low. A summary of the status of the themes at the end of the pre-test is given in Table 4 .

Table 4. Students' status in the pretest result

\begin{tabular}{|c|c|c|c|c|c|c|c|}
\hline Theme & Sub-Theme & Eren & Ilgaz & Mert & Su & Asya & Emre \\
\hline \multirow{2}{*}{$\begin{array}{c}\text { Formulating } \\
\text { Generalizations } \\
\text { Supporting / Evaluation } \\
\text { R1 }\end{array}$} & $\begin{array}{l}\text { Writing Linear } \\
\text { Equations }\end{array}$ & Empty & False & False & $\begin{array}{c}\text { Partially } \\
\text { Right }\end{array}$ & False & Right \\
\hline & $\begin{array}{l}\text { Supporting } \\
\text { Generalizations / } \\
\text { Evaluation }\end{array}$ & Right & $\begin{array}{l}\text { Partially } \\
\text { Right }\end{array}$ & $\begin{array}{l}\text { Partially } \\
\text { Right }\end{array}$ & Right & Right & Right \\
\hline \multirow{2}{*}{$\begin{array}{c}\text { Creating Mathematical } \\
\text { Argument } \\
\text { R2 }\end{array}$} & Formal Explanation & Absent & Absent & Absent & Absent & Absent & $\begin{array}{c}\text { Partially } \\
\text { Right }\end{array}$ \\
\hline & Informal Explanation & $\begin{array}{l}\text { Partially } \\
\text { Right }\end{array}$ & $\begin{array}{l}\text { Partially } \\
\text { Right }\end{array}$ & $\begin{array}{l}\text { Partially } \\
\text { Right }\end{array}$ & $\begin{array}{l}\text { Partially } \\
\text { Right }\end{array}$ & $\begin{array}{l}\text { Partially } \\
\text { Right }\end{array}$ & Right \\
\hline \multirow{2}{*}{$\begin{array}{c}\text { Analyzing Problem } \\
\text { Status } \\
\text { R3 }\end{array}$} & $\begin{array}{l}\text { Understanding the } \\
\text { Problem }\end{array}$ & $\begin{array}{l}\text { Partially } \\
\text { Right }\end{array}$ & Right & Right & Right & Right & Right \\
\hline & Solving The Problem & False & Right & Right & Right & Right & Right \\
\hline $\begin{array}{l}\text { Establishing a } \\
\text { Mathematical } \\
\text { Relationship }\end{array}$ & Inductive Relationship & $\begin{array}{l}\text { Partially } \\
\text { Right }\end{array}$ & $\begin{array}{l}\text { Partially } \\
\text { Right }\end{array}$ & Absent & $\begin{array}{l}\text { Partially } \\
\text { Right }\end{array}$ & $\begin{array}{l}\text { Partially } \\
\text { Right }\end{array}$ & Right \\
\hline $\mathrm{R} 4$ & $\begin{array}{l}\text { Deductive } \\
\text { Relationship }\end{array}$ & $\begin{array}{l}\text { Partially } \\
\text { Right }\end{array}$ & $\begin{array}{l}\text { Partially } \\
\text { Right }\end{array}$ & $\begin{array}{l}\text { Partially } \\
\text { Right }\end{array}$ & Partially Right & $\begin{array}{l}\text { Partially } \\
\text { Right }\end{array}$ & $\begin{array}{c}\text { Partially } \\
\text { Right }\end{array}$ \\
\hline \multicolumn{2}{|c|}{ Verifying Results in Various Results R7 } & Absent & Absent & Absent & Absent & Right & Right \\
\hline
\end{tabular}

\subsection{Findings of the Teaching Experiment Process}

In the teaching experiments, groups formed with a middle and a good student in terms of academic success, coding in line with the given scenarios, observing this coding in the simulation, if they do not reach the desired result, they were told to rewrite the code and complete the process, then they were asked to create tables, patterns, ordered pairs, graphics, verbal generalization clauses and linear equations individually.

\subsubsection{Findings of the $1^{\text {st }}$ Teaching Experiment Session}

In the first session, a parking lot arrangement was given. As explained in Table 3, in this arrangement, a vehicle traveling through the floors goes upstairs to the upper floor in 10 seconds, and when it comes to the related floor, if there is no free space with the help of lights, it goes to the other floor and continues to search for space. It takes an average of 10 seconds to understand whether there is a vacant space. The participants were asked to write the necessary coding that takes this information into consideration. After the scenario was given, codings were made in three groups.

Members of the Group 1, namely Ilgaz and Eren first wrote a robot algorithm that revolves around a rectangular shape (Figure 4a). They loaded this algorithm into the simulation but since they could not observe it in the simulation, they decided to rewrite the algorithm and wrote the second algorithm in Figure 4b. Looking at this algorithm, it is seen that a clearer and systematic code is written. Then they wanted to make observations in the simulation and they decided to decrease their flat travel times because they could not make observations easily in the simulation. Then, it is understood that they wrote the last algorithm in Figure $4 \mathrm{c}$ and interpreted the "stay / wait" command times 2400/800, which they interpreted as a rectangle with the edge length ratio $3 / 1$, to which the robot would proceed. In the process of writing the code of Group 1 it has been observed from the following dialogs (R2) that he analyzed and evaluated the problem situation and decided that they should write a code of navigation around a rectangular region (R3), and created and evaluated informal mathematical 
arguments. Connecting the code they write with the "link" command to the beginning can be thought of as an act to make block codes written across two columns connected to the movements of the robot continuously. Participants showed that they took into account both the rectangular side lengths of the rectangle and the pattern between the path lengths between floors by using the "link" command. This situation shows that they also used the inductive reasoning (R4) that formed and assessed the generalizations of the problem condition (R1), and recognized the pattern of the path of the robot moving around the rectangular region in the transition between floors (mathematical relationship).

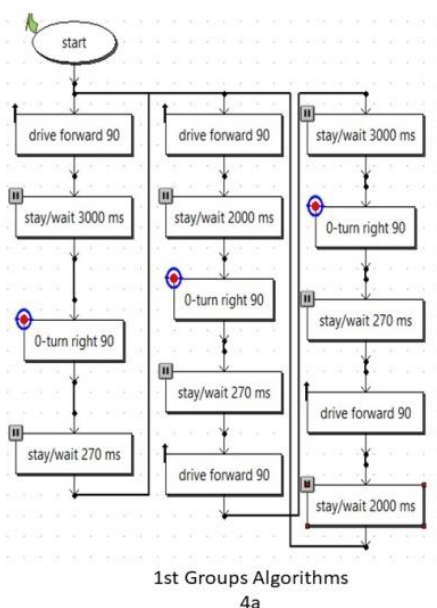

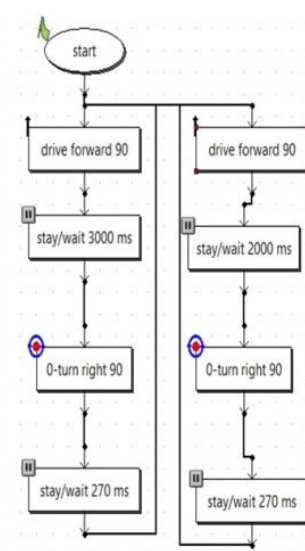

1st Groups Algorithms

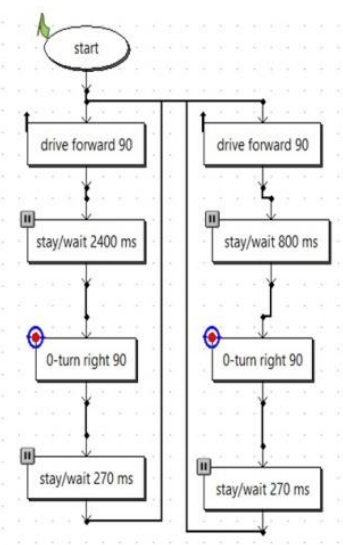

1st Groups Algorithms $4 \mathrm{c}$

Figure 4. Algorithms Written by Group 1 in the Process

While writing the code, Ilgaz and Eren talked among themselves as follows:

Eren: How should we accept the ratio of the edge lengths?

I: Let's take the long edge 3 and the short edge 1 multiple.

E: "Stay/wait" time?

I: How about 1500/500?

E: We cannot observe $500 \mathrm{~ms}$ in simulation.

I: $2400 / 800$ ?

E: It looks logical. Still, we should be able to watch it in the simulation.

I: That's right.

E: We were making a 90 degree turn by 90 right turn and stay / wait 270. Do not forget.

It was observed that Ilgaz and Eren tried to make sense of each other's thoughts and to provide the logic behind them (R5), to continue to argue with asking questions even though they did not create a dispute situation (R6), to support the verification of their results in the simulation (R7).

A section of Ilgaz's worksheet is shown in Figure 5, and it is seen that in the process of creating a linear equation, he reaches the generalization both by using the table and the pattern and by informal mathematical arguments.

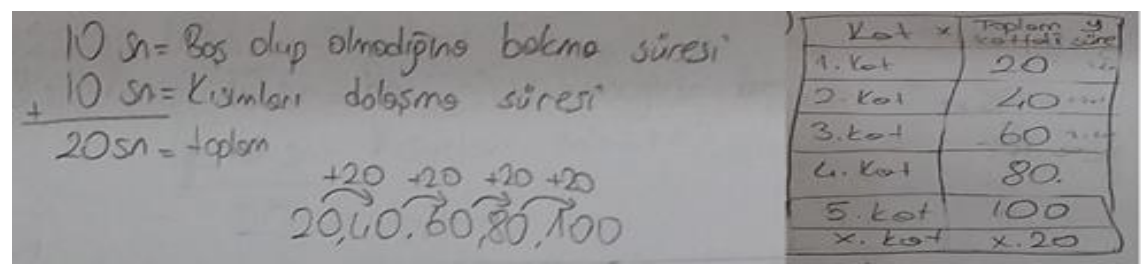

Figure 5. Ilgaz's Answers

After this part, in the continuation of the session, the students were asked to express the number pattern of the first 5 floors of the robot, create the table and reach the generalization of the time lost in the process. In addition, they were asked to individually answer where they were in the 71 st second. Then, the presence of the indicators was analyzed by creating an assumption about the situation in this parking lot and explaining how the equation of this situation would be, if there was no parking guidance system in order to examine and understand the indicators in more depth. At this point, when Eren's working paper was as follows: "if there was no green light information system in the parking lot, the robot's circulation time between floors and how the linear equation of this situation would change would be re-evaluated. I thought it was the time to walk around, 10 times to look at the light, 15 times to look at the ground.) 10 times in 250 seconds; so it will spend more time. This equation becomes $y=25 x$ ”. Eren's statements were made very concrete, and his answer is notable with an attention to 
formulate the new situation. From the point of view of reasoning skills, he can formulate the generalizations he reaches, verifies and supports this new situation (R1), and $\mathrm{Su}$ answered the same question as, "We would spend even more time on that floor if there was no light system. Because the light we understand in 10 seconds while we wait. If there was no light, we would have been walking around that floor and losing more time. Now the parts of a car that are shown in green will be 10 seconds again, but since there is no light system, it will not wait 10 seconds on that floor and will travel on that floor. If this move is 30 seconds, it loses 40 seconds on each floor." Mert said, "If there is no light system in the car park, we will see how the red light is not flashing in the empty space, we will look again when there is no light system, but this time we will not know if the place is empty or not like the light system. This means that we will spend a longer time on our part. So this means that our duration ranges from 20 to 25 seconds. And I mean 25 seconds to this time. "When the statements of all these participants are reviewed, considering their reasoning skills, it can be seen that they can create and evaluate informal mathematical arguments (R2).

At the end of the session, the processes of evaluating the daily life status of the participants in the robotic coding process, thinking of the code to be written for the problem state, discovering the pattern in the problem state while thinking about the code to be written were observed but it was recorded that some progress was necessary. The robots, which are the physical form of coding, contributed to the concretization of the problem state of our participants, attracted the attention of the participants in terms of what the equation meant, in terms of being a new window in transferring the written equations to daily life, and helped to produce a mathematical argument.

\subsubsection{Findings of the $2^{\text {nd }}$ Teaching Experiment Session}

In the second session, the distance of a baby from the wall is $40 \mathrm{~cm}$ and the distance from the fireplace is 100 $\mathrm{cm}$. Erdem, who has just started crawling, can travel $10 \mathrm{~cm}$ per minute and when the fireplace is on, the sensor is activated when Erdem is as close as $20 \mathrm{~cm}$ to the fireplace and parents have a chance to intervene in the situation. It was expected from the groups to write the algorithm that would provide this situation.

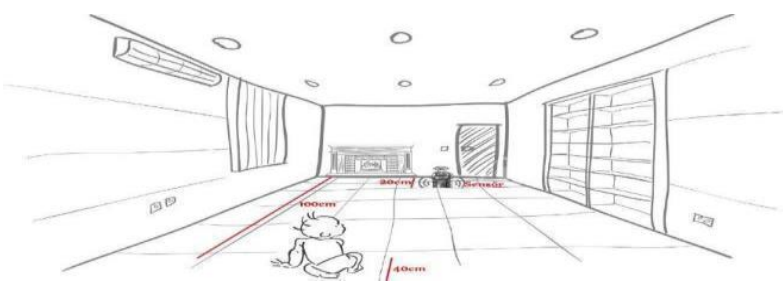

Figure 6. II. Visual of the scenario created for the teaching experiment

When the algorithm by members of Group 3, namely Asya and Emre is examined in Figure 7, it is seen that they paid attention to the burning state of the fireplace, but they did not pay attention to the distance so that the sensor can be activated $20 \mathrm{~cm}$ before the baby reaches the fireplace. Therefore, when analyzing the problem, the variables were analyzed incomplete, and in the second branch, the wrong sensor was used by selecting the motion sensor instead of the distance sensor. In the process of writing this part of the code, the group created mathematical arguments, and made evaluations in line with these arguments (R2), analyzed and evaluated the problem situation (R3). The fact that they connected the code they wrote with the "link" command indicates that they are aware of sensor's need to perform this task constantly, that is, they can see the pattern. In this situation, it can be said that they were able to evaluate generalizations (R1), noticed mathematical relationship and used inductive reasoning (R4). Similar findings were seen in the algorithms of Group 1 and Group 2.

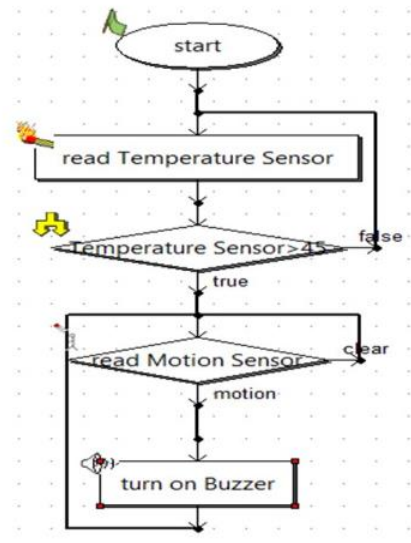

Figure 7. Algorithm Written by Group 3 
After this part students were asked to provide individual answers regarding the table of the Erdem's linear approah to the fireplace in the first five minutes and similarly an equation alond with a table displaying Erdem's movement away from the wall behind him, the baby who can crawl $10 \mathrm{~cm}$ per minute., In the session, the baby's speed was first raised from a speed of $10 \mathrm{~cm}$ per minute to $15 \mathrm{~cm}$ per minute in order to make a more in-depth examination and understanding of the indacators by the participants.. The students were asked how this change in crawling speed change the linear equation and place of the sensor in front of the fireplace. The solution of $\mathrm{Su}$ is given in Figure 8.

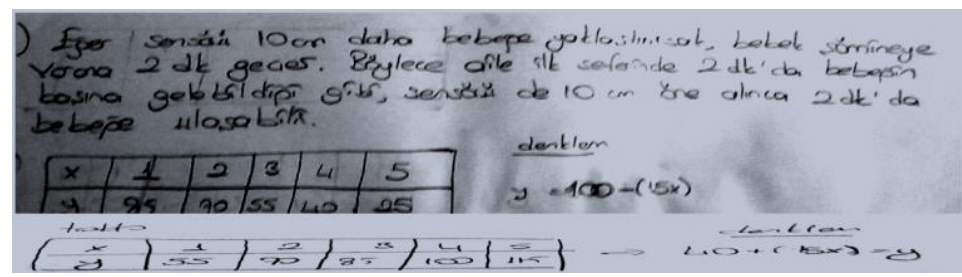

Figure 8. Su's Answer

As can be seen in Figure 8, with the increase of the baby's crawling rate, Su solved the problem by using table and informal mathematical explanations (R3), discovered an inductive mathematical relationship (R4) and turned it into a linear equation. Similarly, as can be seen in the group discussion below, the participants tend to use numerical data to express themselves and to use mathematical relationships (R4).

Researcher: When evaluating the situations that will change with the alteration of Erdem's crawling speed, let's discuss whether the algorithm changes, if it changes, then how the equation will change.

$\mathrm{Su}$ : We must first discuss the situation. When we look at the first case, $20 \mathrm{~cm}$ in front of the sensor fireplace, Erdem travels $10 \mathrm{~cm}$ per minute. There is a logical relationship between this.

Ilgaz: And at the same time, the sensor starts beeping when the baby is as close as $20 \mathrm{~cm}$ to the sensor. Here too there is a logical relationship.

Asya: The first warning comes from the sensor when there is $40 \mathrm{~cm}$ between the baby and the fireplace. So there are 4 minutes of parents in this case. $(R 2)$

Eren: In the new situation, parents will have 2 minutes and 40 seconds $(R 3)$

Emre: An adequate amount of time.

Mert: If we regulate the situation in the question, I think the new location of the sensor should be $30 \mathrm{~cm}$ away from the fireplace.

Asya: Even in the newly written code, there should be a warning when Erdem is $30 \mathrm{~cm}$ away the sensor. (R4)

$\mathrm{Su}$ : Initially it gave 4 minutes to the parents to intervene, so the sensor and the equation should change to regain this time.

Emre: I think 4 minutes is too long. If I hear a little voice, I will run from the room where the baby is alone. I will not change the location of the sensor or the algorithm. (R6)

In dialogs up to this point, it is seen that there is an improvement in analyzing and evaluating the problem in the process of developing informal mathematical argument creation, evaluation and support (R2) reaching to generalizations (R3), and establishing the mathematical relationships (R4) in which the parent can maintain the time given in the first place. In addition, Emre, with his last words, increased the possible discussion (R6) and the dialogue continued as follows.

Researcher: Whatever makes sense for you, you can answer the question accordingly, just reflect it on your papers.

Eren: Actually, what Emre says is logical, after all, 2 minutes and 40 seconds is enough time.

Ilgaz: I think we should write the problem according to the logic of the establishment at the beginning. (R6)

Researcher: As I said, it is enough for you to answer and explain the reason as it makes sense for you. By the way, does Erdem's crawl only affect the sensor?

.... Silence...

Mert: I am confused.

Asya: Me too

Su: Why? (R6)

Mert: Does the displacement of the sensor affect the equation?

... Silence...

Researcher: What are the variables of the equation and the variables of the algorithm? if I ask.

Emre: The algorithm's temperature and distance...

Researcher: Do we agree? 
Asya: We discussed this while writing the code with Emre, now that the baby moves towards the sensor while the fireplace is burning, and we even want the sensor to sound the siren from $20 \mathrm{~cm}$ away. So we have defined two sensors, temperature and distance.

Ilgaz: We made it incomplete. (R5)

Eren: We too.

Researcher: Well, do you think that the variables of Emre and Asya are correct?

E, I, S, M: Yes.

Researcher: So what are the variables of the equation?

Su: We write the equation of the path that Erdem takes on the baby's crawling speed. So Erdem's crawling speed and road.

Mert: Right.

Eren: I still could not understand.

Researcher: Why don't you start by writing the table?

In this section, progress on skills such as making sense of the thoughts of others and understanding the logic behind them (R5) increasing the discussion by asking questions in possible misunderstanding or disagreement (R6) can be seen. After this discussion process, it was asked where the sensor should be placed, what kind of algorithm and linear equation should be placed as the baby's crawling rate changes. A remarkable situation when the responses are examined is that the participants express their ideas very differently from each other, but in the same way. This situation is shown in Table 5.

Table 5. Responses of the participants

\begin{tabular}{cl}
\hline Participant & Responses to the Sensor with Changing Crawling Speed \\
\hline Ilgaz & $\begin{array}{l}\text { Increasing the sensor sensing distance with increasing crawling speed of Erdem baby, that } \\
\text { is, changing the algorithm, but the location of the sensor remains the same } \\
\text { Eren }\end{array}$ \\
Erdem baby's expression of approaching to the wall rather than moving away from the \\
fireplace to change the sensor location with the crawling speed increased \\
Erdem uses the expression to bring the sensor closer to the baby with the crawling speed \\
of the baby. \\
A statement such as removing the location of the sensor by $30 \mathrm{~cm}$ from the fireplace with \\
increasing crawling speed of Erdem baby. \\
It is a reasonable explanation to remove the sensor from the fireplace with the increase of \\
crawling speed of Erdem baby \\
"I think 4 minutes is too long. If I hear a little voice, I will run to the room where the baby \\
is alone. I will not change the location of the sensor or the algorithm. " making an \\
explanation saying
\end{tabular}

If we need to make a general evaluation of this session, it can be said that the groups still could not write enough algorithms, but the development of expressing with linear equation writing and other representations was observed in general. In order to observe R5 and R6, two of the reasoning skills, the discussion reflected above was carried out and each participant was able to express himself/herself through the places they understood or did not understand, without any peer pressure. The most interesting thing is that each of them did not have a complete idea of how the different variables of the algorithm and equation would change according to the crawling rate of the baby before this discussion. Another remarkable situation is that when the whole discussion process of the participants is over and then they answer the questions, they reached to the answer with different expressions with their own sentences as seen in Table 5. For this reason, R7 development is observed in the participants. In addition, it can be said that the answers given at the end of the discussion can be accepted apart from some minor errors and contain different comments due to the effect of writing algorithm, trying the algorithm on the robot and reasoning in silence moments.

\subsubsection{Teaching Experiment Findings}

In this session, six students were asked to write an algorithm by discussing the development of reasoning criteria with experience from the first two sessions, in order to help the groups that were insufficient in algorithm writing and to help them continue to question but not to suppress each other while learning from each other. They were expected to load a 10 -second algorithm on all three robots and create a choreography. While examining the findings, the algorithms of the groups and the algebraic reasoning criteria usedwhile writing these algorithms were first examined, then the individual answers to the questions were interpreted separately for each participant within the framework of the criteria. All participants discussed on a single algorithm with the coding skills they learned up to that point. In this process, it was also possible to "observe the thoughts of others and to grasp the logic behind them" (R5), and to once again observe (R6) indicators in case of possible misunderstanding / disagreement during the exchange of ideas. This situation can be seen in the speeches given below. 
Researcher: You can write an algorithm as you wish, rotating around itself, continuing straight, waiting 1 sec and progressing $3 \mathrm{sec}$. You can also activate all the sensors learned so far, as you wish.

$\mathrm{Su}$ : If the robots turn square, it will be a nice choreography simultaneously.

Eren: It may be different.

Ilgaz: It can be pentagons and hexagons but it would be too difficult.

$\mathrm{Su}:$ Actually, with a rotation angle of $108^{\circ}$ it is possible.

Researcher: Why is it difficult?

Ilgaz: I think it's hard to write this equation. (R6)

Mert: Let it be square. Let's tie a pencil around the edges, and let it show with the drawing that it goes around the square shape. (R6)

Emre: The pencil may be beautiful, but the condition of the floor increases the friction of the robots. In our applications, we see that it cannot go with the sensitivity shown in the simulation even because of battery life, making our work difficult. (R5)

... (the group thinks, and after being convinced) ...

Asya: If we decided to make a square, let's write our algorithm. (R5)

Ilgaz: In fact, if we write an algorithm that will form nested circles, it looks very nice.

Asya: Yes.

Emre: But it is very difficult to write this equation.

Ilgaz: That's right. Square is good.

In the discussion between the participants, Mert and Emre talked about the perception of the path of the robot better from the outside and the use of pens and agreed that this situation may be difficult due to friction. Here, they also convinced their friends by explaining the logic that this could not happen by combining the information that the students learned from other lessons. The discussion has also shown that geometrical information in writing codes is necessary when one of the students talked about the $108^{\circ}$ to create a pentagon.. However, it was observed that they agreed to write a simple algorithm. When asked about the reason, they stated that "they observed the robots implementing a simple algorithm and had the idea that it would be easier to write the equation and the graph because of its implementation". The codes mentioned in the discussions are not simple, but it is a point to consider that they are afraid of writing equations while they are not afraid of writing codes.

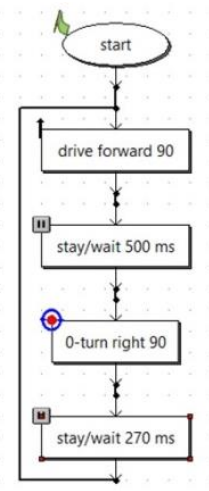

$7 a$

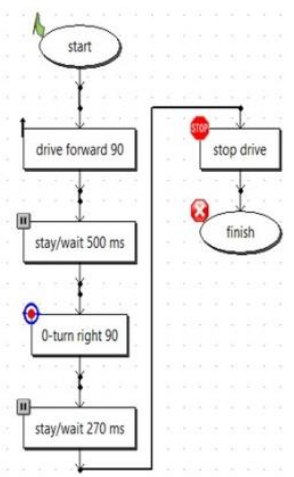

$7 \mathrm{~b}$

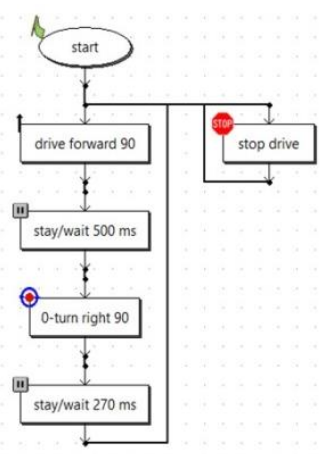

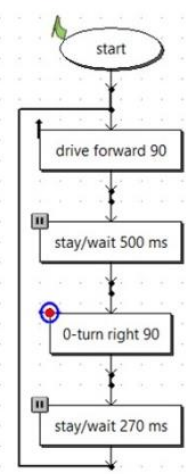

$7 d$

Figure 9. Algorithms Written For The III. Session

As it can be seen from Figure 9, in the first algorithm they created, it is seen that they write a robot algorithm that goes straight for $500 \mathrm{~ms}$, then turns 900, then repeats it, and then turns around a square shape. In the second algorithm, they stated that they wanted the robot to pause a little, but when they saw that the code they wrote was a robot that went straight for $500 \mathrm{~ms}$ and then turned $90^{\circ}$ degrees, they realized that the code they wrote was not working the way they wanted. The revision in the third algorithm has also been an incomplete revision. The last revision was realized when they saw that they could not reach what they wanted in the simulation. The last algorithm is actually very similar to what they wrote first. The only difference is that the robot going straight for $2500 \mathrm{~ms}$ will then turn $90^{\circ}$ degrees, making it easier to observe in accordance with what they say. In the selection of $2500 \mathrm{~ms}$, it was observed in the dialogs that completing the 10 seconds movement was predicated.

As a result, students were expected to load algorithms to the robot, observe the loaded codes, transforme the observed situations to the data such as table, number pattern, verbal generalization and equation, and it has been seen that the participants reflect these situations and it is obvious that this contributes to using multiple representations and converting them. 


\subsection{Findings of Post-Test}

In the last test, an employer put two cooks into the trial process for the kitchen staff who will work in the kitchen, and the number of plates depending on the preparation period of the daily working performances of these two cooks is given on the graph. Then the participants were asked to write a table and sequential binary writing for this graph, to establish a verbal generalization, to write the equation of the plate to be prepared depending on the preparation time, to decide which cook is faster and to decide which cook to hire. In the direction of the answers given in the last test, it was examined as themes. Posttest analyzes are given in Table 6.

Table 6. Students' status in the final test result

\begin{tabular}{|c|c|c|c|c|c|c|c|}
\hline Theme & Sub-Theme & Eren & Ilgaz & Mert & Su & Asya & Emre \\
\hline \multirow{3}{*}{$\begin{array}{c}\text { Formulating } \\
\text { Generalizations } \\
\text { Supporting / Evaluation } \\
\text { R1 }\end{array}$} & Writing Linear & Right & Right & Right & Right & Right & Right \\
\hline & Equations & & & & & & \\
\hline & $\begin{array}{l}\text { Supporting } \\
\text { Generalizations / } \\
\text { Evaluation }\end{array}$ & Right & Right & Right & Right & Right & Right \\
\hline \multirow{2}{*}{$\begin{array}{c}\text { Creating Mathematical } \\
\text { Argument } \\
\text { R2 }\end{array}$} & Formal Explanation & Absent & Absent & Absent & Absent & Absent & $\begin{array}{c}\text { Partially } \\
\text { Right }\end{array}$ \\
\hline & Informal Explanation & Right & Right & Right & Right & Right & Right \\
\hline \multirow{2}{*}{$\begin{array}{l}\text { Analyzing Problem } \\
\text { Status } \\
\text { R3 }\end{array}$} & $\begin{array}{l}\text { Understanding the } \\
\text { Problem }\end{array}$ & Right & Right & Right & Right & $\begin{array}{l}\text { Partially } \\
\text { Right }\end{array}$ & Right \\
\hline & Solving The Problem & Right & Right & Right & Right & Doğru & Right \\
\hline \multirow{3}{*}{$\begin{array}{c}\text { Establishing a } \\
\text { Mathematical } \\
\text { Relationship } \\
\text { R4 }\end{array}$} & Inductive Relationship & Right & Right & Partially & Right & Partially & Right \\
\hline & & & & Right & & Right & \\
\hline & $\begin{array}{l}\text { Deductive } \\
\text { Relationship }\end{array}$ & Right & Right & Right & Right & Right & Right \\
\hline \multicolumn{2}{|c|}{ Verifying Results in Various Results R7 } & Absent & Right & Absent & Right & $\begin{array}{l}\text { Partially } \\
\text { Right }\end{array}$ & Right \\
\hline
\end{tabular}

According to this table, it was seen that they could write linear equations and support generalizations with number patterns and verbal generalizations. When looking at the theme of creating a mathematical argument, the answers were supported with informal arguments, and in this section, it was observed that the number of respondents formed more accurate arguments compared to the pretest. The development of the informal explanation may have had an impact on the robotic coding process and the discussion processes they formed with each other. However, it is clear that the development of developing an argument for mathematical situations contributes to mathematical understanding and algebraic reasoning. It can be said that understanding and solving the problem in the theme of analyzing the problem situation is one step better than the pretest. It was observed that the participants who had problems in analyzing the problem status in the pretest can easily analyze the problem status in the post-test and use the representation form in explaining the problem status. It is thought that encountering different problem situations and trying to produce answers to these problems together, and then to respond by themselves made an impact on the theme of problem situation analysis. Informal orientation is quite high in establishing a mathematical relationship, and an increase in the correct response appears. It is seen that the use of inductive and deductive forms of relationship has increased in establishing mathematical relationships. However, verification of the results in various subjects was quite limited as in the pretest and no improvement was observed.

\section{Conclusion, Discussion and Suggestions}

This study aimed to investigate the development process of algebraic reasoning in linear equations in algebra sub-learning. The developments of the participants were examined in Table 1 considering the themes given as algebraic reasoning indicators (formulating generalizations, generating mathematical arguments, analyzing problem status, establishing mathematical relations, verifying the results in various subjects).

Firstly, the results obtained in the theme of "formulating generalizations" are presented considering the pretest, teaching experiment process and posttest. While formulating the generalizations, it can be seen that the students can establish an equation correctly in the pretest, while other students have difficulties in establishing the linear equation in the format $y=a x$ or $y=a x+b$. During the teaching experiments, it was observed that some groups realized the pattern between the rectangular side lengths of the rectangle and the path lengths 
between the floors in the process that the group members tried to create the algorithm together. In addition, in another teaching experiment, some groups were found to be able to indicate the relationship between time and travel by equation. During the teaching experiment, it was observed that the students transform the situations observed within the scope of the scenarios into a table, number pattern, verbal generalization and equation. At this point in the study, it was concluded that in the final test applied at the end of the teaching experiment, all participants were able to formulate all generalizations correctly, establish the relationship between the variables and convert them into equations. However, the result showing that students can reflect the rectangle's side lengths and the distance between floors into the algebraic expression does not coincide with research made by Atasoy and Bulut (2018) and Dindyal (2004), both claiming that students had difficulty in interpreting the change in geometrical shape features and algebraic expression The algorithms they encoded in the coding process may have helped them to try this situation by watching them in the simulation.As a result, the fact that participants in this research can formulate generalizations can be said to be helpful in their utilization of algebraic reasoning in the coding process.. On the other hand, in the future studies, besides the algebraic reasoning of the participants, the development in algebraic thinking levels with coding can be examined. In the study, coding trainings start at kindergarten level in our country and in the world, starting from the development in the process of formulating generalizations and making sense of what these representations mean. Therefore, educational robotics applications can be done in algebra learning areas at other grade levels.

In the theme of "creating a mathematical argument", students were able to partially reflect the arguments informally while answering the questions in the pretest. During the teaching experiments, it was observed that the participants tried to create a mathematical argument by using the number patterns, writing tables, creating an equation and discussing with all the participants in the group. Since in-group discussions through argumentation reveal different ways of thinking and questioning, mathematical ideas can be analyzed and it has been observed that they develop in geometric concept knowledge and understanding (Uygun \& Akyuz, 2019). Similarly, in our study, the participants produced arguments (Yackel \& Cobb, 1994) using mathematical language in the group and collective discussion environment, thereby increasing their knowledge of linear equations. In the last test applied at the end of the teaching experiments, it was seen that all participants made mathematical arguments by making correct informal explanations. In this context, it can be said that students within the scope of the study can create a mathematical argument while coding in educational robotics applications.

In the theme of "analyzing the problem situation", it was seen that the participants benefited from the useful information provided in case of a problem and transformed multiple representation forms. As Silik (2016) stated, it has been observed that by using robotic applications, students gained many skills such as learning by living, problem solving, finding practical solutions to problems, critical thinking, awareness of their own abilities, increased levels of technology use and more willingness to use technology. It can be said that this result of our study coincides with the situations expressed by Silik.

In the theme of "establishing a mathematical relationship", the participants were able to reflect, in part, to establish mathematical relations in the pretest. In particular, it was determined that some of the participants did not take into account that the points on the axis were equally spaced. This situation coincides with the result by Gürbüz and Şahin (2015) in their research examining 8th grade students' transitions between multiple representations and found out that the students did not pay attention to the distances between the units and placed the numbers. During the teaching experiments, especially in the last teaching experiment session, the participants made a decision by associating geometry information with their code writing status and were able to establish mathematical relationships easily. They realized that the participants needed to turn around $90^{\circ}$ to rotate around the rectangular shape and write code knowing that the robot would travel around the edge length of the rectangle. In the last test, it was determined that most students associate their problem situations with daily life, create table values based on graphic representation, and transition from graphic representation to algebraic expression was realized by half of the students. This finding does not coincide with the studies stating that students have difficulty in creating an equation based on graphic representation (Knuth, 2000; Tekay \& Doğan, 2015). In addition, it was determined that the participants made the algorithm experiments they made in the process making a connection between simulation and real life. As a result, it can be said that educational robotics applications have a positive effect on the association process between daily life and subjects. Based on this, in future studies, educational robotics applications can be applied to different subjects and learning areas in education programs and learning outcomes can be investigated. For example, talking about angle values while talking about turning the robot at a certain angle is an important indicator that studies on polygons can be done in the field of geometry. Apart from this, it was observed that geometry information was related with linear equations in algebra subject area. The contribution of educational robotics applications to inter-subject correlation can also be examined.

R5 "Understanding others' thoughts / ideas / approaches and providing logic behind them" and R6 "Asking questions and increasing discussion in cases of misunderstanding or disagreement" are not discussed in thematic analysis either in pre-test or post-test because these indicators are indicators that can be observed with 
interpersonal communication and comments on their development. Sfard (2007) stated that learning is a change in communication and proposed a common framework for defining mathematical learning. In other words, a student's mathematics learning can be assessed by observing the language they use to talk about mathematics. Considering the development of this indicator in the sessions process, while this interaction was less in the first sessions, II. discussion on the concept of variable in the session, III. it is clear that the discussion has improved on the common algorithm to be written in the session. Although it is a process skill for participants to establish mathematics, in particular the issue of linear equations, mathematical thinking in the process of interpretation, is a process skill (Kabael \& Ata-Baran, 2016), it is a written and verbal form of arguments that include the solution process in solving and justifying mathematical problem situations. (OECD, 2013). It is seen that the participants took part in similaractions during the sessions. Peer communication contributes to mathematical language development (Pellegini et al., 1997), but it is not sufficient for language development alone (Topping et al., 2004), as well as communication, peer interaction is recommended (Hoff, 2006). According to Steffe (1991), the field of convergent development as a mathematical concept occurs as a result of interaction in a constructivist learning environment. As a result of the exchange of mathematical ideas in interaction with a more competent or adult individual, the learner reconstructs his existing mathematical knowledge. This structuring process allows the difference between the two levels to get closer (Pritchard \& Woollard, 2010). In the study, the three participants were medium in terms of academic success and three were good. It was determined that some participants knew different robotic coding programs previously and this situation contributed to their development. In addition, it is clear that the dialogues in the sessions contribute to the criteria of making sense of the opinions of others and increasing the discussion in case of misunderstanding. Therefore, it can be said that this teaching experiment process contributed to the development of algebraic reasoning.

In the theme of "verifying the results on various issues", it can be said that the participants did not develop at the expected level. The last part of the open-ended questions used in teaching experiments is about the change of variables in the given scenarios and how this change will affect the answers of the question. Both these responses should be individually answered sections and the number of teaching experiment sessions conducted may be insufficient. Again, the fact that the 7th grade linear equations subject of this study focused on the parts of the curriculum and the limitation of the number of teaching experiments in the curriculum may have led to the failure to see the necessary development in this theme. In future studies, this indicator can be focused on as a reasoning indicator. Again, on the one hand, considering the fact that gifted students who can develop various perspectives by nature need richer learning environments associated with multiple disciplines, the effect of educational robotics applications on gifted individuals can be examined. It is thought that richer interpretations can be obtained in terms of this theme. 


\section{Doğrusal Denklemlerde Yapılan Eğitsel Robotik Uygulamalarının Cebirsel Akıl Yürütme Üzerindeki Etkileri}

\section{Giriş}

Bireyin ve toplumun biçimlenmesinde önemli yeri olan teknolojinin son yllardaki hızlı değişimleriyle bireylerden beklentiler değişmektedir (Akgündüz ve ark., 2015). Bu beklentiler içerisinde üst düzey düşünme becerileri karşımıza çıkabilir. Yüzyıllardır toplumları yönetenlerde olması gereken problem çözme, işbirliği yapabilme, yaratıcılık ve eleştirel düşünme gibi beceriler 21. yüzyılda evrensel okuryazarlık olma yolundadır (Akgündüz ve ark, 2015).Bu beklentiler bireylerin bilgiyi hazır alan değil, bilgiyi yorumlayan, hayatında işlevsel bir şekilde kullanabilen, eleştirel düşünebilen, problem çözebilen, kararlı, girişimci, empati yapabilen, iletişim becerileri gelişmiş, topluma katkı sağlayan bir bireyi tanımlamakta kullanılabilir (Milli Eğitim Bakanlığı [MEB], 2018). Tüm bu nedenler ile birlikte teknolojiyi tüketen değil üreten bireyler yetiştirmenin de öneminin arttığg söylenebilir. Son beş yılda teknoloji destekli ürünler üretmek isteyen toplumların eğitim ortamlarında çeşitli eğitsel robotik uygulamalarının yaygınlaştığı görülmektedir (Freeman, Adams-Becker, Cummins, Davis ve Hall Giesinger, 2017). Eğitici robotlar üzerinde dünya genelinde birçok ülke yaygın olarak araştırmalar yapmakta ve bu ülkelerin başında; Japonya, Kanada, Yeni Zelanda, Güney Kore, Avustralya, Tayvan, Amerika Birleşik Devletleri, Portekiz gibi ülkeler gelmektedir. Japonya Robot Derneği (JARA), Uluslararası Robotik Federasyonu (IFR) ve Birleşmiş Milletler Ekonomik Komisyonu (UNEC) kurumları, son yıllarda eğitim alanında ve pazar payında robotların, ciddi bir şekilde büyüdüğünü ve önümüzdeki on yılda daha da hızla büyüyeceğini aktarmaktadırlar (Barreto ve Benitti, 2012).

Robotik etkinlik/yarışma ve çalışmalarının da ülkemizde gitgide ilgi çeken bir noktada olduğu bilinmektedir (Aksu, 2019; Göksoy ve Yılmaz, 2018; Kıran, 2018; Zengin, 2016). Ancak dünyada ve ülkemizde robotlarla ilgili çalışmalar genellikle kurs, kulüp ve proje kapsamında yürütülmüştür (Çavaş ve Huyugüzel-Çavaş, 2005; Gennari, Dodero ve Janes, 2012; Koç-Şenol ve Büyük, 2015; Şişman ve Küçük, 2018; Witherspoon, Reynolds, Copas ve Alagic, 2004). Ülkemizde çoğunlukla özel okullarda, devlet okullarında ise öğretmenlerin kişisel çabalarıyla bilişim teknolojileri dersinde veya kulüp etkinlikleri kapsamında, birçok üniversitede ise çocuklar için robotik yaz kamplarıyla eğitsel robotik uygulamalarına yer verilmeye başlanmıştır (Şişman ve Küçük, 2018). Eğitsel robotik uygulamaları disiplinlerarası çalışmalara yönelik olumlu görüşs (Zengin, 2016) ve etkili öğrenme ortamı (Şişman ve Küçük, 2018) oluşturmada katkı sunar. Bu çalışmayı özgün kılan bir taraf ise robotik uygulamalarının kulüp aktivitesi, robotik yarışmalarında kullanılmasının ötesinde matematik dersi kazanımlarıyla ilişkilendirilerek problem durumu karşısında kod yazarak öğretimde ders uygulama aracı olarak kullanılmasıdır. Ayrıca matematiksel akıl yürütmenin özel alanlarından biri olan cebirsel akıl yürütmenin gelişimine de katkı sağlayacağını düşünülmektedir. Bu nedenle problem durumları karşısında katılımcıların robotik kodlama yaparken ve ardından robotun hareketlerini gözlemleyip oluşan durumları çoklu temsil biçimleriyle ifade etmesi, böylelikle cebirsel akıl yürütme gelişiminin gözlenmesi hedeflenmiştir.

\subsection{Robot Matematiği}

Son yıllarda popülerleşen ve yeni bir teknoloji alanı olan 'Robotik", robotların çalışma ve kullanımını, robotların modelleme, tasarlama ve programlama süreçlerini içeren teknoloji alanıdır (Silik, 2016). Robotik teknoloji, eğitim alanında eğitimcilere teknolojiyle bütünleştirilmiş, robotik öğretim programı katkısını sunar. Bunun yanında gelişmiş teknoloji uygulamalarını öğrenme ortamı içerisinde robotlar üzerinde gerçekleştirerek öğrenmenin daha anlamlı, kalıcı olmasını sağlamak ve elde edilen bu bilgi ve becerilerin günlük yaşantılarını kolaylaştıracak pratik ve kuramsal ürünler ortaya koymalarını sağlamak amacıyla kullanılmaktadır (Wood, 2003). Robotik, robotlarla ilgili yapılan programlamayı, inşayı ve tasarım süreçlerini içeren programlamanın görünür bir teknoloji dalıdır (Karsan-Erbaş, 2014). Son yıllarda eğitsel robotik çalışmaları Fen, Teknoloji, Mühendislik ve Matematik [FeTeMM] eğitimine destek olması, temel bilgi ve becerileri kazandırma amaciyla kullanılmaktadır (Üçgül, 2013). FeTeMM dersleri müfredatı incelendiğinde, öğrencilerin eleştirel düşünme, sorgulama becerilerinin ve problem çözme robotik etkinlikleri kullanılarak geliştiği ortaya çıkmıştır (Talim ve Terbiye Kurulu Başkanlığı [TTKB], 2006a, 2006b, 2009). Robotik uygulamaların öğrencilerin problem çözme becerisinin (Eguchi, 2010; Gerecke ve Wagner, 2007; Goldman, Eguchi ve Sklar, 2004; Göksoy ve Yılmaz, 2018; Ribeiro, 2006; Silik, 2016), eleştirel düşünme becerisinin (Eguchi, 2010; Jimoyiannis ve Komis, 2001; Gerecke ve Wagner, 2007; Ribeiro, 2006; Silik, 2016), teknolojiyi kullanma düzeylerinin (Silik, 2016; Ribeiro, 2006), yaratıcı düşünme becerisinin (Eguchi, 2010; Gerecke ve Wagner, 2007; Göksoy ve Yılmaz, 2018; Jimoyiannis ve Komis, 2001; Lin ve ark., 2009) gelişimine katkı sunduğu görülmektedir. Nitekim birçok çalışma robotik faaliyetlerinin FeTeMM eğitimi üzerinde birçok olumlu etkisinin olduğunu göstermektedir (Alimisis, 2013; Barreto ve Benitti, 2012; Bruciati, 2004; Eguchi, 2010; Küçük ve Şişman, 2017; Liu, Lin, Feng ve Hou, 2013; Gerecke ve Wagner, 2007).

Çavaş ve Huyugüzel-Çavaş (2005) yaparak-yaşayarak öğrenmenin ve eğlenceli bir şekilde tasarlanmasının öğrenmeyi en üst noktalara çıkardığı ayrıca öğrenmenin kalıcılığını arttırdığını belirtmişlerdir. Dünyada eğitimde 
robotiğin kullanımını araştırmaya yönelik yapılan eğitim çalışmalarına bakıldığında, robotiğin eğitimde öğrenciler için önemli bir zenginleştirilmiş öğrenme ortamı olduğu açıktır (Koç-Şenol ve Büyük, 2015). Bu bağlamda günümüz çağdaş eğitiminin amaçları arasında tarif edilen bireyin yetiştirilmesi için de bu tür zenginleştirilmiş öğrenme ortamlarında yaparak yaşayarak öğrenmeyle öğrenmenin kalıcılığı da arttırılabilir.

Papert (1972) de öğrencilerin aktif olarak sürece katıldıklarında ve anlamlı ürünler tasarlayıp oluşturduklarında en iyi şekilde öğrenebildiklerine vurgu yapmaktadır. Zamanla gelişen eğitsel robotik uygulamalarında öğrenciler öğrenme sürecinin her aşamasında aktif rol almaktadırlar (Alfieri, Higashi, Shoop ve Schunn, 2015). Bu süreçte öğrenciler, robotları tasarlamakta, oluşturdukları robotları programlamakta ve sonuçlarını anında görebilmektedirler. Bu durum öğrencilerin varsayımlar oluşturması, bu varsayımları test etmesi, doğrulaması, doğrulayamama durumunda yeniden varsayım oluşturması ve sürecin sonunda problemin çözümüne yönelik bir sonuca ulaşılmasına katkı sunmaktadır. Ayrıca öğrenciler robotlarını blok tabanlı ya da metin tabanlı görsel programlama araçlarıyla programlarken bu süreçte robotların kızılötesi, dokunma, renk ve ses gibi çeşitli sensörleri kullanılarak çevreyle etkileşime girmeleri sağlanmaktadır. Böylece öğrenciler belirledikleri amaçlar doğrultusunda farklı işlevleri yerine getirebilen özgün robotik projeleri geliştirebilmektedirler. Alan yazında yapılan çalışmalar eğitsel robotik uygulamalarının öğrencilerin bilimsel süreç becerilerini geliştirmede de etkili olduğunu göstermiştir (Eguchi, 2010; Gerecke ve Wagner, 2007; KoçŞenol ve Büyük, 2015; Lin ve ark., 2009). Yine Papert (1993) kodlama etkinliklerin sınıf öğretimini geliştirmek için muazzam bir potansiyele sahip olduğuna inanmaktadır. Bununla birlikte Williams, Ma, Prejean, Lai ve Ford (2007), robotik uygulamaların okul öncesi öğreniminden lise öğreniminin sonuna kadarki (K-12) öğretim programı üzerindeki etkisini kanıtlamak için sınırlı ampirik kanıt olduğunu teyit etmektedir. Eğitimciler, matematik, fen ve mühendislik dahil olmak üzere çeşitli konuların öğretimine robotik dahil etmek için fikirler üretmeye ve etkinlikler geliştirmeye başlamıştır. Bir yandan da Johnson (2003) tarafindan öğrencilerin akademik performansı üzerindeki doğrudan etkisini destekleyen bir araştırma sonucu olmadığı robotik faaliyetlerin sadece "moda" olabileceğini zorluk olarak sunulmuştur. Araştırmacılar, eğitimde robotik kullanımı ile ilgili alan yazınının çoğunun, bireysel inisiyatiflerle olumlu sonuçlar elde eden öğretmenlerin raporlarına dayanarak, tanımlayıcı nitelikte olduğunu vurgulamaktadır (Williams ve ark., 2007; Caci, Cardaci ve Lund, 2003).

Robot matematiği ise; teknoloji, mühendislik ve matematiğin disiplinlerarası birleşimidir, öğrencilere disiplinlerarası bakışın önemini ve bu disiplinlerin birbirlerini niçin gerekli kıldıklarını ve bir yandan da birbirlerini nasıl kolaylaştırdıklarını ifade eder (Alfieri ve ark., 2015). Araştırmacılar robotik derslerinin öğrencilerin matematiksel kavramları anlamlandırmasını pekiştirmede olası kullanımına odaklanmaktadırlar (Barreto ve Benetti, 2012; Vollstedt, Robinson ve Wang, 2007'den akt., Dinçer-Kucuş ve Cantürk-Günhan, 2017, s. 621). Robotik-matematik, özellikle robotik üzerine odaklanan matematik öğretimini tanımlamak için kullanılan bir terimdir (Dinçer-Kucuş ve Cantürk-Günhan, 2017). Öğrenciler robotik kodlama sürecinde, problem durumu için kodlama yaparken somut bağlamda matematiksel problemlerle karş̧laşabilirler. Farklı içerikte matematiksel problemlerle karşılaşma, öğrenciye robot matematiği bağlamında hem deneyim hem de özgüven kazandırabilir. Buna bağlı da öğrencinin daha hızlı bir şekilde matematiksel kavramı anlamlandırma ve sezme kabiliyetine ulaşacağı öngörülebilir. Matematiksel kavramları anlamdırması öğrenciyi öğrenmeye daha da yaklaştırır. Bu sebeple robotik matematik sürecinde öğrencilerin matematiksel becerilerini nasıl yansıttıkları incelenebilir. Bu araştırma kapsamında da öğrencilerin cebirsel akıl yürütme becerilerinin incelenmesi amaçlanmıştır.

\subsection{Cebirsel Akıl Yürütme}

Akıl yürütme, muhakeme bir başka deyişle usavurma bütün etmenleri dikkate alarak düşünüp akılcı bir sonuca ulaşma sürecidir (Kaya ve Keşan, 2014). Bir konuda akıl yürütebilenler, o konuyla ilgili yeterli bilgi seviyesine sahip ve yeni karşılaştı̆ı bir durumu her boyutuyla inceleyip mantıklı tahminler ve varsayımlarda bulunarak düşüncelerini gerekçelendirebilirler, ardından bazı sonuçlara ulaşıp ulaşılan sonucu açıklayabilir ve savunabilirler (Umay, 2003). Akıl yürütme kısaca mantıksal düşünme, yargıya varma, sonuç çıkarma olarak ifade edilebilir. Çelik'in (2007) belirttiği gibi akıl yürütme bireyleri gelecekteki akademik ve iş hayatına hazırlamanın yanında, onları yaşama hazırlamak açısından da çok önemli bir yere sahiptir. Akıl yürütme sayesinde düşünüp etkili kararlar verildiğinden akıl yürütme yaşamı kolaylaştırıcı özelliği olan önemli bir yetenektir (Erdem, 2011). Matematiksel akıl yürütme ise yeni ortaya çıkan matematiksel fikirler ile birlikte keşfetmeyi, bireylerin neden sorusuna yanıt ararken problemi yapılandırmasını, açıklanmasını, yorumlamasını ve onaylanmasını içerir (Kasmer, 2008). Cebirsel akıl yürütme ise matematiksel akıl yürütmenin bir bileşenidir (Nilklad, 2004). Cebirsel akıl yürütme kavramının içini dolduran akıl yürütme, temsil kullanma, sembolik temsillerin anlamını açıklama, değişkenleri anlama, temsiller arasında dönüşüm yapma, problem çözme, matematiksel fikirlerin gelişimi için modellerle çalışma gibi matematik için hayati becerileri içeren bir düşünme şeklidir (Kaf, 2007). Dolayısıyla cebirsel akıl yürütme, matematik öğretiminde bütün sınıf seviyelerinde öne çıkan bir kavram denilebilir. Bunun yanında cebirsel akıl yürütme becerisi yalnızca matematik dersinde değil günlük hayatta bireylerin karşılaştıkları güçlükler üzerinde düşünmeye, yorumlamaya ve çözüm yolu aramaya yönelik etkinlikler de içermektedir (Bike-Kalkan, 2014). Bu etkinlikler öğrencide düşünme, yorumlama ve 
çözüm yolu arama gibi zihinsel süreçleri etkileyebileceği düşünülmektedir. Belki de bu etkinlikler sınıf ortamında uygun öğretim yöntem ve teknikler kullanılarak öğrencilerin akıl yürütme becerilerinin gelişimi sağlanabilir.

Cebirsel akıl yürütme ise bir problem durumunda bilgiyi kelimeler, tablolar, grafikler ve denklemler gibi farklı temsil biçimleriyle ifade edebilme; matematiksel yapıları, sembolleri, araçları ve işlemleri anlamlı kullanma; örüntüleri formüle edip denklem oluşturma, fonksiyon ve bağıntıları anlayabilme ve tümevarımsal ve tümdengelimsel düşünmeyi içeren akıl yürütme biçimidir (Driscoll, 1999; Greenes ve Findell, 1998; Herbert ve Brown, 1997; Kaput, 1999; Kieran ve Chalouh, 1993; National Council of Teachers of Mathematics [NCTM], 2000). Yani cebirsel akıl yürütme; değişkenleri genelleme, temsil biçimlerinin birbirine dönüşümü ve hesaplamalar yoluyla soyutlamaları kapsayan akıl yürütmenin bir türü olarak tanımlanmaktadır (Vance, 1998). Tüm bu tanımlamalar dikkate alındığında cebirsel akıl yürütme becerisinin bireydeki gelişiminin oldukça önemli olduğu söylenebilir. Cebirsel akıl yürütme becerilerinin yönelik göstergeler Tablo 1'de yansıtılmıştır. Bu Tablo 1 'deki göstergeler, Kasmer (2008) tarafından NCTM (Ulusal Matematik Öğretmenleri Konseyi) ve TIMMS'in (Uluslararası Matematik ve Fen Eğilimleri Araştırması) bilişsel alanının beklentilerini benimseyerek geliştirmiştir (akt., Bike-Kalkan, 2014, s.14). Bike Kalkan'ın (2014) çalışmasında da Türkçeleştirilmiş ve "cebirsel muhakeme göstergeleri” olarak vermiştir.

Yapılan bu çalışmada yukarıda bahsedilen kavramsal çerçevenin tercih edilmesinin nedeni sistematik göstergeler içermesi, alanyazın temsil gücü, 2017-2018 eğitim öğretim yılı öğretim programlarında ifade edilen kazanımları gözlemlemeye yardımcı olmasıdır. Ayrıca bireylerin yukarıdaki göstergelerin çoğunu bireysel olarak yansıtabilecek iken AY5 ve AY6 göstergelerine dikkat edilecek olursa "başkalarının düşüncelerini/ fikirlerini/ yaklaşımlarını anlamlandırma..” ve “...sorular sorma ve tartışmayı artırma” gibi ifadelerden öğrencilerin bir araya gelmesi durumunu yansıttığı için bu çalışmada da grup çalışmalarına yer verilmiştir.

Tablo 1. Cebirsel Ak1l Yürütme (AY) Göstergeleri

\begin{tabular}{|c|c|}
\hline Gösterge & Gösterge Açıklamaları \\
\hline AY(1): & $\begin{array}{l}\text { Genellemeleri formüle etme, değerlendirme ve destekleme: } \\
\text { Herhangi bir durum için doğru bir şeyler hakkında bir açıklama yapabilmedir. }\end{array}$ \\
\hline AY(2): & $\begin{array}{l}\text { Matematiksel argümanları oluşturma, değerlendirme ve destekleme: } \\
\text { Özel ya da genel bir durum hakkında informal ya da formal bir açıklama yapabilme, yani en } \\
\text { son genelleme için bir varsayım yapabilmedir. }\end{array}$ \\
\hline AY(3): & $\begin{array}{l}\text { Problem durumunu analiz etme ve değerlendirme: } \\
\text { Çözüm için problemden yararlı bir bilgi ortaya çıkarabilmedir. }\end{array}$ \\
\hline AY(4): & $\begin{array}{l}\text { Matematiksel ilişkiyi kurmak/desteklemek için tümevarım ve tümdengelim muhakemeyi } \\
\text { kullanmak: } \\
\text { Tümevarımsal muhakemeyi kullanmak, örüntü çalışmalarında matematiksel ilişkiyi } \\
\text { arayabilme, tümdengelimsel muhakemeyi kullanmak ise, belirli bir durumda bulunan bir } \\
\text { örüntüyü desteklemek için kurulan matematiksel bir ilişkiyi kullanabilmektir. }\end{array}$ \\
\hline AY(5): & $\begin{array}{l}\text { Başkalarının düşüncelerini/ fikirlerini/ yaklaşımlarını anlamlandırma ve bunların arkasındaki } \\
\text { mantığı sağlama: } \\
\text { Eleştirel/değerlendirici bir yaklaşımla diğerlerinin mantığının ve muhakemesinin kabul edilip } \\
\text { edilemeyeceğini anlayabilmedir. }\end{array}$ \\
\hline AY(6): & $\begin{array}{l}\text { Yanlış anlama ya da anlaşmazlık durumlarında sorular sorma ve tartışmayı artırma: Açıklama } \\
\text { isteme ya da karşıt bir görüşs sağlayabilmedir. }\end{array}$ \\
\hline AY(7): & $\begin{array}{l}\text { Çeşitli konulardaki sonuçları doğrulama ve destekleme: } \\
\text { Bir genelleme ya da bir argüman yapma zorunluluğu olmadan bulguları özetleyen bir } \\
\text { açılklama yapabilmedir. }\end{array}$ \\
\hline
\end{tabular}

Bu çalışmada kodlama ve doğrusal denklem konusunun birlikte düşünülmesinin nedeni, cebirsel akıl yürütme süreçleriyle kodlama süreçlerinin benzer yolları içermesidir denilebilir. Kodlama, çözülecek bir problemde örüntüleri adım adım ilişkilendirerek oluşturup çözüme nasıl ulaşacağının belirleme sürecidir (Üzümcü ve Erdal, 2018). Böylelikle yirmi birinci yüzyıl becerilerinin gelişiminde, teknolojiyi üretebilen teknoloji destekli matematik eğitimi alanına yeni bir yönelim daha eklenebilir. Bu noktada bu çalışmanın amacı idea o-bot robotik yazılımını bilen ortaokul öğrencileri ile matematiksel öğrenme ortamı oluşturup cebir alt öğrenme alanında yer alan doğrusal denklemlerde cebirsel akıl yürütmenin gelişim sürecini incelemektir. Araştırma problemi ise: "Ĕ̈itsel robotik uygulamalarının tasarlanan bir ögretim deneyi yöntemiyle 7. sinıf ögrencilerinin doğrusal denklemler konusunda cebirsel akıl yürütmenin gelişimi nasıldır?” olarak belirlenmiştir. Bu probleme ait alt problemler ise aşağıdaki gibidir: 
- “Eğitsel robotik uygulamalar öncesi 7.sınıf ögrencilerinin doğrusal denklemler konusunda cebirsel akıl yürütme gelişimi nasıldır?"

- "Eğitsel robotik uygulamalarının ögretim deneyi sürecinde, 7. sınıf öğrencilerinin doğrusal denklemler konusunda cebirsel akıl yürütmenin gelişimi nasıldır?”

- "Eğitsel robotik uygulamalar sonrası 7. Sinıf ögrencilerinin doğrusal denklemler konusunda cebirsel akıl yürütmenin gelişimi nasıldır?"

\section{Yöntem}

$\mathrm{Bu}$ araştırma ile yedinci sınıf öğrencilerinin eğitsel robotik uygulamalarla doğrusal denklemlerde cebirsel akıl yürütme becerilerinin gelişimi incelenmek amaçlandığı için nitel araştırma yaklaşımları tercih edilmiştir. Çünkü nitel araştırma yaklaşımları araştırma örnekleminin davranışlarını doğal ortamında derinlemesine sorgulamayı amaçladığından araştırmacıların araştırılan konuda derinlemesine bilgiye ulaşmasını sağlamaktadır (Lempp ve Kingsley, 2007). Çalışmada nitel yaklaşım çerçevesinde öğretim deneyi deseni kullanılmıştır. Öğretim deneyi öğrencilerin matematiksel gerçekleri anlaması ve bu süreçteki davranış örüntülerini ortaya çıarmada kullanılabilecek etkili bir yöntemdir (Lesh ve Kelly, 2000; Steffe, 1991; Steffe ve Thompson, 2000). $\mathrm{Bu}$ çalışmada da öğrencilerin araştırma süreci öncesinde öğretim programları doğrultusunda zihinlerinde bulundurdukları doğrusal denklemlere dair bilgilerden ve idea o-bot kullanabilme bilgilerinden yola çıkarak cebirsel akıl yürütmenin nasıl geliştiğinin anlamlandırılması için öğretim deneyi yöntemi kullanılmıştır.

\subsection{Katılımcılar}

$\mathrm{Bu}$ araştırmada katılımcılar, amaçlı örneklemenin ölçüt örnekleme yöntemiyle seçilmiştir. Amaçlı örnekleme, zengin veri sağlayacağı düşünülen durum ve olayların yorumlanması, açıklanması ve derinlemesine incelenmesi amacıyla seçilmektedir (Yıldırım ve Şimşek, 2005). Ölçüt örneklemede ise belirlenmiş ölçüt ya da ölçütleri karşılayan durumlar çalışılmaktadır ve söz konusu ölçütler önceden oluşturulmuş bir listeden alınabilir ya da araştırmacı tarafından hazırlanabilir (Yıldırım ve Şimşek, 2005). Bu çalışmadaki katılımcıları Muğla ili, merkez ilçesinde bulunan bir ortaokulunda 7. sınıf öğrencileri oluşturmaktadır. Araştırmada seçilen 6 öğrencinin seçiminde dört temel ölçüt dikkate alınmıştır. Bu ölçütler;

- temel düzeyde kodlama biliyor olması,

- matematik dersi başarısının orta ve yüksek olması,

- kendisini iyi ifade edebilen öğrenciler olması,

- öğrencilerin gönüllü olmasıdır.

Katılımcılar belirlenirken matematik öğretmenleri ve bilişim öğretmenin fikirleri alınmıştır. Çalışmada katılımcıların takma isimleri kullanılmıştır. Katılımcıların özellikleri Tablo 2'de verilmiştir.

Tablo 2. Katılımcıların özellikleri

\begin{tabular}{cccc}
\hline Takma İsmi & Akademik Başarısı & Kendini ifade etme & Başka programlar bilmesi \\
\hline Ilgaz & Yüksek & İyi & Bilmiyor \\
Eren & Orta & İyi & Bilmiyor \\
Su & Yüksek & İyi & Bilmiyor \\
Mert & Orta & Iyi & Biliyor \\
Asya & Orta & İyi & Bilmiyor \\
Emre & Yüksek & İyi & Biliyor \\
\hline
\end{tabular}

Çalışmada, katılımcıların akademik başarısına göre bir orta bir yüksek olacak şekilde iki kişilik gruplar oluşturulmuş ve bu gruplarda katılımcıların yakınsal gelişim alanlarında birbirlerine destek olacak şekilde öğrenme ortamı oluşturulmuştur.

\subsection{Veri Toplama Araçları}

Araştırmada veri toplama aracı olarak katılımcılara uygulanan ön test, öğretim deneyi sürecindeki görevler ve son test kullanılmıştır. Cebirsel akıl yürütme göstergeleri doğrultusunda geliştirilen ön test, öğretim deneyi görevleri ve son test hazırlanırken öğretim programı kazanımları dikkate alınarak hazırlanmıştır. Ardından tüm süreçte kullanılacak araçların akıl yürütme göstergelerin uygunluğuna ilişkin bir alan eğitimcisi, deneyimli iki matematik öğretmenin görüşleri alınmıştır. Ön testte katılımcılara 7 soru yöneltilmiştir. Öğretim deneyi üç oturumdan oluşmaktadır ve her bir oturumda bir senaryo kapsamında görevler verilmiştir. Birinci oturumda $y=a x$ denklemi, ikinci oturumunda ise $y=a x+b$ denklemi içinde gelişen birer senaryo ve görevler doğrultusunda sorulan sorular ile cebirsel akıl yürütme becerileri ölçülmeye çalışılmıştır. Üçüncü oturum ise AY5 ve AY6 göstergelerinin ancak grup çalışmaları sırasında gözlenebilmesi üzerine hazırlanmıştır. Son testte de katılımcılara 6 soru yöneltilmiştir. Tablo 3'te de bu veri toplama araçlarının içeriklerinde katılımcılardan beklenenler ve soruların bulundurduğu göstergeler verilmiştir. 
Tablo 3. Soru, Göstergeler ve Beklentiler

\begin{tabular}{ll}
\hline Veri Toplama Aracı & \\
& A \\
& Bir antik tiyatronun koltukları \\
& aşağıdan yukarıya A,B ve C \\
& olarak isimlendiriliş üç bölüme \\
& ayrılmıștır. Bu bölümlerden A \\
& ve C olarak isimlendiriliş \\
& bölümlerde koltuklar aşağıdan \\
Ön Test & yukarıya birer, B olarak \\
& isimlendirilen bölümde ise \\
& ikişer artar. Antik tiyatroda \\
& koltuk sayılarının doğrusal \\
& artı̧ına dair; \\
B & Topla yapılan bir sporda topun \\
maç sürecinde izlediği yolun \\
zamana bağlı grafiğine dair;
\end{tabular}

$\mathrm{Bu}$ duruma yönelik sayı örüntüsü ve tablo yazması Gösterge

\section{beklenir}

AY 2-3

$\mathrm{Bu}$ durumun genellemesinin sözel ifadesi ve doğrusal denklemini yazması beklenir.

İstenen bölümde koltuklarda kaç seyirci oturacağını hesaplaması beklenir.

Oluşacak durumun doğrusal denkleminin grafiğinin çizilmesi beklenir.

Başlangıçta verilen soru kökünde verilen ifadelerde değişim olduğunda denklem ve koltuklarda oturabilecek kişi sayısının değişiminin açıklanması beklenir.

Topun maç sürecinde izlediği yolun zamana bağlı grafiğinin yorumunu yapabilmesi beklenir.

AY $1-2-4-7$

Benzer şekilde başka bir spora ait zamana bağlı değişim grafiği çizmesi beklenir.

Bu süreçte gerekli olacak algoritmayı grup arkadaşıyla

kodlanmayı oluşturması beklenir.

$\mathrm{Bu}$ duruma yönelik sayı örüntüsü ve tablo yazması beklenir.

$\mathrm{Bu}$ durumun genellemesinin sözel ifadesi ve $y=a x$

Otopark yönlendirme sistemi Öğretim kullanan 10 Katlı bir otoparkta Deneyi 1 boş bir alana araç park etmesi istenen robota dair; formatında doğrusal denklemini yazması beklenir.

İstenen saniyede robotun nerede olacağını açıklayabilmesi beklenir.

Robotun aldığı yolun zamana bağlı grafiğinin çizilmesi beklenir

Otopark yönlendirme sistemi olmasa bu otoparkta oluşacak duruma yönelik bir varsayım oluşturup bu durumun denkleminin nasıl olacağının açıklanması beklenir.

Grup arkadaşıyla bu durumu sağlayacak bir kod yazması beklenir.

AY 1-2-3-4-7

Bir bebeğin dakikada emekleyerek aldığı yolu dikkate

Bir odanın içerisinde bulunan şömine ve şömineden $20 \mathrm{~cm}$ $\begin{array}{llr}\text { Öğretim uzaklıkta bir sensör } \\ \text { bulunmaktadır. } & \text { Şömine }\end{array}$ Deneyi 2 bulunmaktadr. yanarken sensöre 20 cm'den fazla yaklaşıldığında uyarı verecek bir kod yazmaya dair; alarak bulunduğu noktadan şömineye yaklaşmasının istenen sürede tablosunu ve $y=a x+b$ formatında denklemini yazması beklenir.

Aynı durumun tam tersinden yorumlanarak duvardan uzaklaşma denklemini $y=a x+b$ formatında yazması beklenir.

Bebeğin emekleme hızının artması durumunda odadaki sensörün yerinin ve bebeğin aldığı yolun zamana bağlı doğrusal denkleminin değişimini açılaması beklenir.

3 adet robotla 10 saniyelik koreografi oluşturmaları beklenir.

Öğretim

Deneyi 3
A bir işe başvuran iki aşçının (A ve B) performansının grafiği Son Test verilmiştir. Buna yönelik;

B

Topla yapılan bir sporda topun maç sürecinde izlediği yolun zamana bağlı grafiğine dair;
On saniyelik sürecin saniyede alınan yol olarak tablosunun oluşturulması, sıralı ikililer yardımıyla grafiğinin çizilmesi beklenmektedir.

Tercih edilen saniye aralıklarının doğrusal denkleminin yazılması beklenir.

Aşçı A ve Aşçı B'nin zamana bağlı hazırladıkları tabak sayılarının tablosunun oluşturulması ve sıralı ikililerinin yazılması beklenir.

İki aşçının belirtilen süre içerisinde hazırlayabildiği tabak sayısına dair yorum yapabilmesi beklenir.

İki aşçı için yemeği hazırlama süre (t) ile hazırlanan tabak (p) arasında oluşan durumun genellemesi ve sözel ifadesini yazması beklenir.

İşverenin deneme süreci sonunda kimi ișe alması gerektiğini gerekçelendirerek açıklaması beklenir.

AY 1-2-3-4-

AY 1-3-4

AY $2-3$

AY 4

AY 1-2-4-7

AY 3-5

Topun maç sürecinde izlediği yolun zamana bağlı grafiğinin yorumunu yapabilmesi beklenir.

Benzer şekilde başka bir spora ait zamana bağlı değişim grafiği çizmesi beklenir
AY 3

AY 7 
Gerek öğretim deneyi sürecinde gerek de ön test ve son test soruları cevaplandırılırken katılımcıların izni alınarak tüm süreç kayıt altına alınmıştır. Bu kayıtlardaki ve öğrencilerin cevaplarını yazdıkları kağıtlardan elde edilen bulgular da araştırmaya yansıtılmıştır.

\subsection{Verilerin Analizi}

Öğretim deneyinden elde edilen verilerin analizi, geriye dönük ve ileriye dönük analiz olmak üzere iki şekilde yapılmaktadır. İleriye dönük analiz, araştırmacının süreç içerisinde uygulamaları devamlı şekilde analiz etmesi ve bunun neticesinde öğretim ve öğrenmenin daha iyi hale getirilmesi için alternatif öğrenme yollarını ortaya koymasıdır (Cobb, Confrey, Disessa, Lehrer ve Schauble, 2003). Geriye dönük analiz ise, çalışma sonunda toplanan bütün verilerin analiz edilerek ortaya konulan modelin güvenilir ve tutarlı olduğunun gösterilmesidir (Cobb, 2000; Cobb ve ark., 2003; Steffe ve Thompson, 2000). Bu çalışmada da öğretim deneyi sürecinin analizinde her uygulama sonrası ileriye dönük analizler yapılmış, bir sonraki uygulamaya bu analizler 1şığında devam edilmiştir. Ön test, öğretim deneyi süreci ve son testte öğrencilerin durumları Tablo 1'deki göstergeler 1şı̆̆ında "genellemeleri formüle etme, matematiksel argüman oluşturma, problem durumunu analiz etme, matematiksel ilişki kurma, çeşitli konulardaki sonuçları doğrulama" temaları oluşturularak içerik analizi ile incelenmiştir. Bu temalarda öğrencilerin akıl yürütme göstergelerin yansıtmaları aşağıda Genellemeleri Formüle Etme Destekleme/ Değerlendirme temasına göre örneklendirilmiştir;

Doğru : Öğrenci doğrusal denklemi doğru bir şekilde yazabilmiştir.

Klsmen Doğru: Öğrenci doğrusal denklemi kısmen yazabilmiştir.

Yanlış: Öğrenci doğrusal denklemi yanlış yazmıştır.

Boş: Öğrenci soruyu boş bırakmıştır.

Ayrıca soruların anlaşılıp anlaşılmadığını anlamak amacıyla 7. sınıfta öğrenim gören iki öğrenciyle pilot uygulama yapılmış, testler ve öğretim etkinliklerinde bulunan maddelerin daha açık ve anlaşılır olması için tekrar düzenleme yapılmıştır. Araştırmanın geçerliğini sağlamada; veri toplama araçları geliştirilirken alan yazın ve uzman görüşleri dikkate alınmıştır. Ses kayıtları yazıya dökülmüş, araştırmacılar tarafından kontrol edilmiştir. Verilerden elde edilen kodlamalar araştırmacılar tarafından 6 ay arayla yapılmış, bu iki analiz arasında uyum yüzdesi \%95 olarak hesaplanmıştır. Ayrıca oturum sonlarında katılımcılarla açık uçlu sorulara verdikleri yanıtlarla ilgili "burada ne düşündün?", "buraya bu ifadeyi yazma sebebini sorabilir miyim?" gibi sorular yöneltilerek ham verilerle elde edilen sonuçlar sürekli karşılaştırılmış, böylece teyit edilebilirlik sağlanmıştır. Aktarılabilirlik için katılımcıların ifadelerinden doğrudan alıntılara yer verilmiştir.

\subsection{Uygulama Süreci}

Araştırmanın asıl uygulamasından önce öğretim deneyinin bir pilot uygulaması yapılmıştır. Pilot uygulamada öğretim deneyi iki oturumda gerçekleşmiş ve süreç analiz edildiğinde öğrencilerde gözlemlenmesi beklenen "başkalarının düşüncelerini/ fikirlerini/ yaklaşımlarını anlamlandırma ve bunların arkasındaki mantığ sağlama"(AY5) ile "yanlış anlama ya da anlaşmazlık durumlarında sorular sorma ve tartışmayı arttırma" (AY6) cebirsel akıl yürütme göstergelerinin yeterince gözlenemediği fark edilmiştir. Bu sebeple üçüncü bir öğretim deneyi oturumu tasarlanmış, uzman görüşü alınmış ve uygulanmıştır. Bu pilot uygulama, asıl uygulamadan iki hafta önce tamamlanmıştır. Asıl çalışma grubuyla öğretim deneyi üç oturum olarak gerçekleştirilmiştir. Öğretim deneylerini birer hafta arayla yapılmıştır. Çalışmanın uygulama süreci ön ve son test ile beraber beş hafta sürmüştür. uygulama sürecini anlatan şema Şekil 1'de verilmiştir.

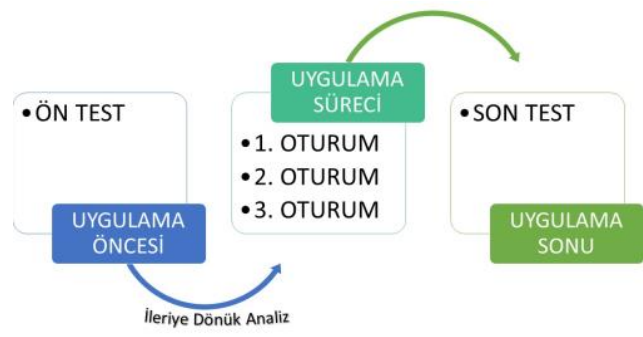

Şekil 1. Uygulama Şeması

Birinci oturumda Tablo 3 'te ifade edilen senaryo verilmiş ve katılımcılardan bu senaryo gereği hareket edecek idea o-bot'un hareketlerinin (senaryodaki problem durumu karşısında yönergeleri gerçekleştirme) algoritmasını Grup1:Ilgaz-Eren, Grup2:Su-Mert, Grup3:Asya-Emre olacak şekilde üç farklı gruptan yazmaları istenmiştir. Kodları yazma süreçleri tamamlandıktan sonra senaryo üzerinden sorular yöneltilmiş, bireysel olarak yanıtlamaları istenmiştir. İkinci oturumda da yeni bir senaryo verilmiş ve bu senaryo gereği idea o-bot'un sensörlerinin hareketi ve sıcaklı̆̆ı algılayacak bir algoritma yazması yine aynı gruplardan istenmiştir. Birinci oturumdaki süreç gibi gruplar kodları beraber yazdıktan sonra soruları bireysel olarak cevaplamışlardır. Bu oturumda senaryodaki değişkenlerden bazıları değiştirildiğinde oluşacak yeni algoritma ve denklem üzerine 
tartışırken katılımcıların kafalarında bir belirsizlik oluştuğu gözlenmiştir. Bu belirsizlik algoritma ve denklemin değişkenlerini birbirinden bağımsızken senaryodaki değişikliğin her iki durumun değişkenlerini de farklı biçimlerde etkiliyor olmasındandır. Bu nedenle ikinci oturumda bireysel yanıtlara geçmeden önce, değişken kavramı üzerine tartışma yürütülmüştür. Üçüncü oturumda katılımcıların robotlarını dans ettirmeleri için birlikte koreografi oluşturmaları bu koreografiyi de algoritmaya yansıtmaları, ardından algoritma sonucu robotun hareketlerini denklem ve diğer temsil biçimlerine dönüştürmeleri beklenmiştir. Her bir oturum yaklaşık bir saat sürmüştür.

\section{Bulgular}

Bu bölümde araştırmada katılımcılara yöneltilen ön test soruları, üç öğretim deneyi oturumu boyunca sorulan sorular ve son testte yöneltilen soruların yanıtları analiz edilmiştir.

\section{1. Ön Test Sorularının Bulguları}

Ön testte bir antik tiyatroda bulunan koltukların dizilimi verilmiş bu dizilim üzerinden aynı durumun sayı örüntüsü, tablo, grafik, sözel genelleme cümlesi, doğrusal denklemi ve belirli bir sırada kaç koltuk olacağının hesaplanması istenmiştir. Bir de verilen bir grafik üzerinden topun süreçteki yüksekliği üzerinden hangi spor olabileceğini yorumlamaları ve kendi sevdikleri bir spor dalı için zamana bağlı topun yerden yüksekliği için grafik çizmeleri istenmiştir. Bu bölümde katılımcılardan alınan bulgular ön testte verilen yanıtlar doğrultusunda temalar halinde incelenmiştir. Bu temalar; genellemeleri formüle etme, matematiksel argüman oluşturma, problem durumunu analiz etme, matematiksel ilişki kurma, çeşitli konulardaki sonuçları doğrulama biçimindedir.

Testin “Bir antik tiyatroda koltuklar üç bölümden oluşmakta ve A ve C bölümlerinde ilk sırada 10'ar koltuk bulunmakta olup her sirada koltuk sayıs 1 artmaktadır. B bölümünde ise ilk sirada 20 koltuk bulunmakta olup her sırada koltuk sayısı 2 artmaktadır. Koltuk sayıları her sütunda ikişer artsaydı doğrusal denklem nasıl olurdu” sorusunda katılımcılardan Su " $(8+2 x) .3$ ” yanıtı vererek soruda ilk sırasında onar koltuk bulunan A ve C sırası için genellemeye ulaşabilmiş, ancak yirmi koltuk bulunan B sırası için ulaşamamıştır. Dolayısıyla ön testte genellemeleri formüle edebilmede konusunda kısmen başarı gösterdiği söylenebilir. Ilgaz ise " $B$ ' $d e$ hiç değişiklik olmazdı çünkü B'de zaten 2 'şerli artıyor” demiştir. Ilgaz'ın bu yorumu informal matematiksel bir argüman üretebildiğinin göstergesidir. Asya'nın tümevarma sürecinde informal açıklamalar yaptığı kâğıdındaki ifadeler " $A$ ve C siralarında birer koltuk artışı varken B de iki koltuk artmaktadır." ve " $A$ ve C'de yeni durumda toplam dört artış olurdu, B değişmezdi." şeklinde olduğu görülmüştür. Asya, yanıtlarında verileri arası matematiksel ilişki kurabildiği görülmektedir. Çeşitli konulardaki sonuçları doğrulama teması açısından bakıldığında da Emre'nin sorulan bir soruda verdiği yanıt Şekil 2'de görüldüğü üzere hem doğrusal denklemle hem de sözel genellemeyle desteklediği ve doğruladığı görülmektedir.

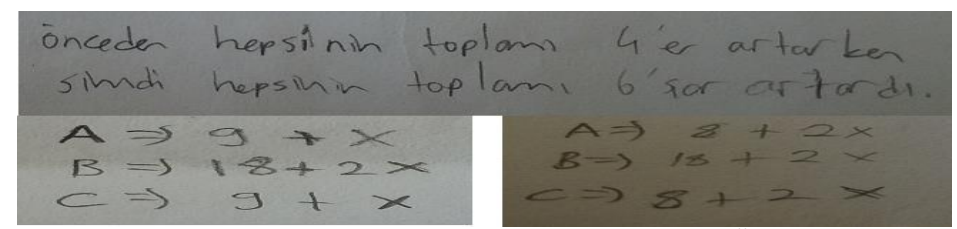

Şekil 2. Emre'nin Sonuçlarını Doğrulama Örneği

Katılımcılardan Emre'nin ise problem çözüm sürecinde soruda verilen grafiği saniyeye bağlı çözümlemesinin doğru yanıta ulaştırdığı Şekil 3’te görülmektedir. Problemi çözerken verilen grafikten yararlandığı ve kendi ilgilendiği sporun süreye bağlı aldığı yol grafiğini doğru çizdiği görülmüştür. Problem durumunu analiz etme temasında problemden yararlı bilgiyi ortaya çıkarabildiği ve bu açıdan da yeterli olduğu söylenebilir.
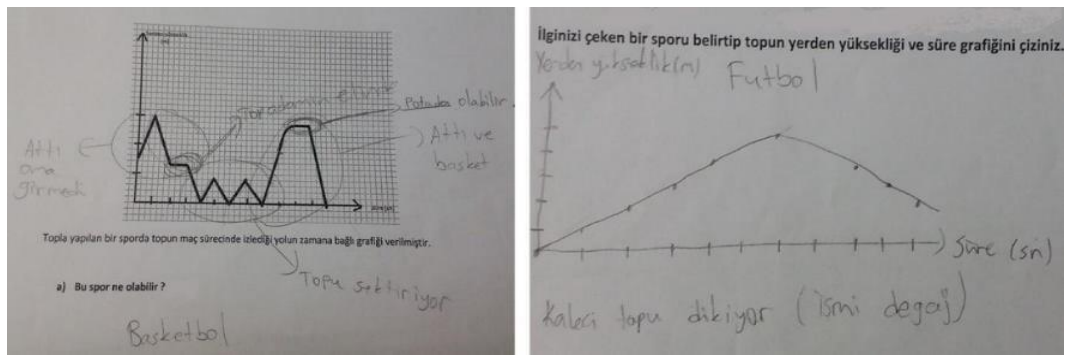

Şekil 3. Emre'nin Grafik Yorumlaması ve Çizimi

Ön test analizlerini genel olarak ele almak gerekirse genellemeleri destekleme temasına bakıldığında tablo temsilinin tüm katılımcılar tarafından kullanıldı̆̆ı, sayı örüntüleriyle temsil ve destekleme ise üç katılımcının yanıtlarında görülmüştür. Sözel genellemeye dört katılımcının ulaşabildiği ancak katılımcıların genel olarak 
$y=a x$ veya $y=a x+b$ formatında doğrusal denklem kurmakta zorlandıkları görülmüştür. Argüman oluşturma sürecinde formal açıklama yalnızca bir katılımcı tarafından yapılmış olup genel eğilimin informal açıklama yönündeki yine katılımcıların yarısında gözlenebilmiştir. Problem durumunu analiz ederken tablodan tüm katılımcılar faydalanmış, örüntüden yarı yarıya faydalanma varken grafik ve denklemden için birer katılımcının faydalandığı görülmüştür. Matematiksel ilişki kurma temasına bakıldığında gerek tümevarımsal gerekse tümdengelimsel açıklamaların informal olduğu dikkati çekmiştir. Son tema olan çeşitli konulardaki sonuçları doğrulama temasında yanıt ise oldukça azdır. Tüm öğrencilerin ön test sonucunda temalardaki durumların özeti Tablo 4'te verilmiştir.

Tablo 4. Öğrencilerin öntest sonucundaki durumları

\begin{tabular}{|c|c|c|c|c|c|c|c|}
\hline Tema & Alt Tema & Eren & Ilgaz & Mert & Su & Asya & Emre \\
\hline \multirow{5}{*}{$\begin{array}{l}\text { Genellemeleri Formüle } \\
\text { Etme Destekleme/ } \\
\text { Değerlendirme } \\
\text { AY1 }\end{array}$} & Doğrusal Denklem & Boş & Yanlış & Yanlış & Kismen & Yanlış & Doğru \\
\hline & Yazma & & & & Doğru & & \\
\hline & Genellemeleri & Doğru & Kismen & Kismen & Doğru & Doğru & Doğru \\
\hline & Destekleme/ & & Doğru & Doğru & & & \\
\hline & Değerlendirme & & & & & & \\
\hline \multirow{4}{*}{$\begin{array}{c}\text { Matematiksel Argüman } \\
\text { Oluşturma } \\
\text { AY2 }\end{array}$} & Formal Açıklama & Yok & Yok & Yok & Yok & Yok & Kismen \\
\hline & & & & & & & Doğru \\
\hline & İnformal Açıklama & Kismen & Kismen & Kismen & Kismen & Kismen & Doğru \\
\hline & & Doğru & Doğru & Doğru & Doğru & Doğru & \\
\hline \multirow{3}{*}{$\begin{array}{c}\text { Problem Durumunu } \\
\text { Analiz Etme } \\
\text { AY3 }\end{array}$} & Problemi Anlama & Kismen & Doğru & Doğru & Doğru & Doğru & Doğru \\
\hline & & Doğru & & & & & \\
\hline & Problemi Çözebilme & Yanlış & Doğru & Doğru & Doğru & Doğru & Doğru \\
\hline \multirow{4}{*}{$\begin{array}{c}\text { Matematiksel İlişki } \\
\text { Kurmak } \\
\text { AY4 }\end{array}$} & Tümevarımsal İlişki & Kismen & Kismen & Yok & Kismen & Kismen & Doğru \\
\hline & & Doğru & Doğru & & Doğru & Doğru & \\
\hline & Tümdengelimsel İlişki & Kismen & Kismen & Kısmen Doğru & Kısmen Doğru & Kismen & Kismen \\
\hline & & Doğru & Doğru & & & Doğru & Doğru \\
\hline \multicolumn{2}{|c|}{ Çeşitli Sonuçlardaki Sonuçları Doğrulama AY7 } & Yok & Yok & Yok & Yok & Doğru & Doğru \\
\hline
\end{tabular}

\section{2. Öğretim Deneyi Sürecinin Bulguları}

Öğretim deneylerinde akademik başarı yönünden bir orta, bir iyi öğrenci ile oluşturulan grupların verilen senaryolar doğrultusunda kodlama yapmaları, bu kodlamayı simülasyonda gözlemlemeleri, eğer istedikleri sonuca ulaşamamaları halinde yeniden kod yazmaları ve süreci tamamlamaları, ardından bireysel olarak senaryonun devamında sorulan sorularla tablo, örüntü, sıralı ikili, grafik, sözel genelleme cümlesi ve doğrusal denklem yazmaları istenmiştir.

\subsubsection{I. Öğretim Deneyi Oturumunun Bulgulart}

İlk oturumda bir otopark düzeneği verilmiştir. Tablo 3'te de açıklandığı gibi bu düzenekte katları dolaşan bir araç otoparkta bir üst kata 10 saniyede çıkar, ilgili kata geldiğinde de ışıklar yardımıyla boş yer yoksa diğer kata çıkıp yer aramaya devam eder. Boş yerin olup olmadığını anlamasında ortalama 10 sn sürer. Katılımcılardan bu bilgileri dikkate alan gerekli olacak kodlamayı yazmaları istenmiştir. Senaryo verildikten sonra üç grup halinde kodlamalar yapılmıştır.

Grup 1 elamanları Ilgaz ve Eren öncelikle bir dikdörtgensel şekil etrafinda dönen robot algoritması yazmıştır (Şekil 4a). Bu algoritmayı simülasyona yüklemiş ancak simülasyondaki gözlemleyemedikleri için algoritmayı yeniden yazma kararı alıp Şekil 4b'deki ikinci algoritmayı yazmışlardır. Bu algoritmaya bakıldığında daha net, sistematik yazılmış bir kod yazıldığı görülmektedir. Ardından simülasyonda gözlem yapmak istemiş ve yine simülasyonda rahat gözlem yapamadıkları için düz gitme sürelerini düşürme kararı almışlardır. Ardından Şekil 4c'deki son algoritmayı yazıp robotun ilerleyeceği yolu kenar uzunlukları oranı 3/1 olan bir dikdörtgen gibi yorumlamış oldukları "kal/bekle" komutu sürelerini 2400/800 belirlemelerinden anlaşılmaktadır. Kodu yazma sürecinde Grup 1; problem durumunu analiz edip değerlendirmiş ve bir dikdörtgensel bölge etrafinda dolaşma kodu yazmaları gerektiğine karar vermiş (AY3), informal matematiksel argümanlar oluşturup değerlendirmiş olduğunu aşağıdaki diyaloglardan (AY2) gözlemlenmektedir. Yazdıkları kodu "bağla" komutu ile başa bağlamak, iki sütun boyunca yazılan blok kodları robota sürekli yaptırma komutu gibi düşünülebilir. Katılımcılar burada "bağla" komutu kullanarak gerek dikdörtgenin karşılıklı kenar uzunluklarının eşit olması bilgisini gerekse de katlar arası yol uzunlukları arasındaki örüntüyü dikkate alarak kod yazdıklarını gösterir. Bu durum da problem durumuna ait genellemeleri oluşturmuş ve değerlendirebilmiş (AY1), katlar arası geçişte dikdörtgensel 
bölge etrafında hareket eden robotun aldığı yolun örüntüsünü yani matematiksel ilişkiyi fark etmiş tümevarımsal akıl yürütmeyi (AY4) kullanmıştır.

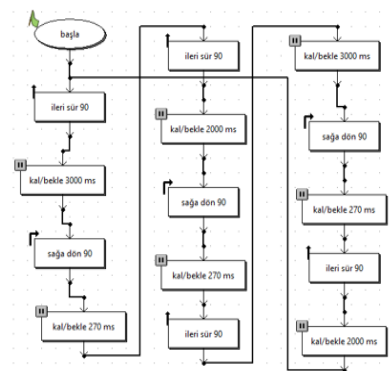

Grup 1'in Yazdı̣̆̆ llk Algoritma $4 \mathrm{a}$

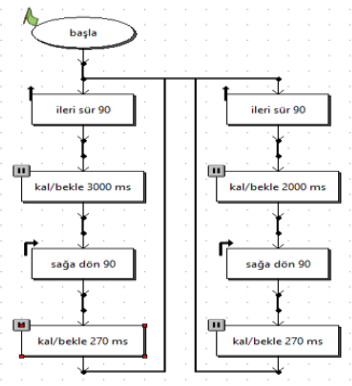
Grup l'in Yazdğ̀ Itkinci Algoritma

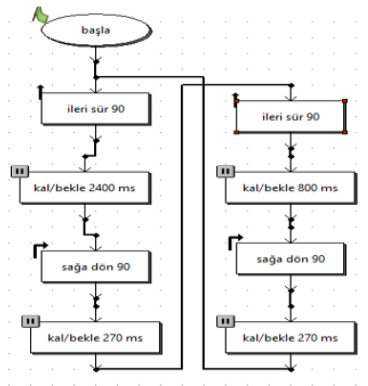

Gup 1'in Yazdığı Son Algoritma

Şekil 4. Grup 1'in Süreçte Yazdıkları Algoritmalar

Kodu yazarken Ilgaz ve Eren'in kendi aralarında;

E: Kenar uzunluklarının oranını nasıl kabul etmeli?

I: Uzun kenarl 3, kisa kenarı l'in katı alalım.

E: "Kal/bekle" süresi?

I: $1500 / 500$ 'e ne dersin?

E: 500 ms'yi gözlemleyemiyoruz simülasyonda.

I: $2400 / 800$ ?

E: Mantıklı görünüyor. Yine de simülasyonda da izlemeli.

I: Doğru.

E: să̆a dön 90 ve kal/bekle 270'yle 90 derecelik dönüş yapıyorduk. Unutmayalım.

Ilgaz ile Eren'in yukarıda yansıtılan diyaloglarından birbirlerinin düşüncelerini anlamlandırma ve arkasındaki mantığ 1 sağlamaya çalışmaya (AY5) çalıştıkları, anlaşmazlık durumu oluşturmasa da soru sormakla tartışmayı devam ettirdikleri (AY6), verilerin doğruluğunu simülasyonda gözlemlemek istemeleri de sonuçlarını doğrulama destekleme (AY7) ihtiyacı duydukları gözlenmiştir.

Ilgaz'ın çalışma kağıdından bir bölüm Şekil 5'te görülmekte olup doğrusal denklem oluşturma sürecinde böylelikle gerek tablodan ve örüntüden faydalanarak gerekse de informal matematiksel argümanlarla genellemeye ulaştığı görülmektedir.

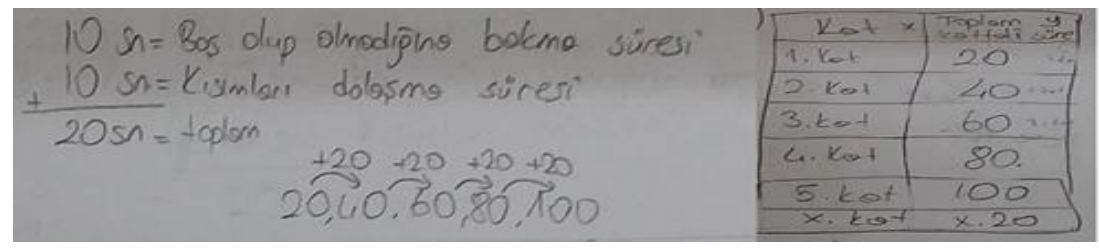

Şekil 5. Ilgaz'ın Yanıtları

Bu kısımdan sonra oturumun devamında robotun ilk 5 katı çıkması sürecinin sayı örüntüsünü ifade etme, tablosunu oluşturma; bu süreçte yolda kaybedilen süreyle ilgili genellemeye varma; 71. saniyede nerede olduklarını bireysel olarak cevaplamaları istenmiştir. Ardından göstergelerin katılımcılarda daha derinlemesine incelenmesi ve anlaşılabilmesi için otopark yönlendirme sistemi olmasa bu otoparkta oluşacak duruma yönelik bir varsayım oluşturup bu durumun denkleminin nasıl olacağının açıklanmasıyla göstergelerin varlığı analiz edilmiştir. Bu noktada Eren'in çalışma kağıdı incelendiğinde otoparkta yeşil 1şıkla bilgilendirme sistemi olmasaydı robotun katlar arası dolaşım süresi ve bu durumun doğrusal denklemi nasıl değişir yeniden değerlendiriniz sorusuna; "Yer bakması ışık bakmaktan daha uzun olacă̆ için 20-10+15=25 saniye (20 sistemli dolaşma süresi, 10 ışık bakma süresi, 15 yer bakma süresi olarak düşündüm.) sürede 10 katı 250 saniyede; yani daha fazla zaman harcayacaktır. $y=25 x$ olur"demiştir. Eren'in açıklamaları oldukça somutlaştırılmış, kendince yeni durumu formüle etmesi dikkat çekmiştir. Akı1 yürütme becerileri yönünden bakıldığında ulaştığ1 genellemeleri formüle edebildiği bu yeni durumu doğrular ve destekler açıklamaları yapabildiği (AY1), aynı soru karşısında Su ise " Ĕger ışık sistemi olmasaydı o katta daha da zaman harcarız. Çünkü lşık 10 saniyede biz beklerken ışıkla anlıyoruz. Ĕger ışık olmasaydı biz kendimiz o katta dolaşacak ve daha çok süre kaybedecektik. Şimdi bir araba yeşille gösterilmiş kısımları yine 10 saniye olacaktı ancak ışık sistemi olmadiğ için o katta 10 saniye beklemeyecek o katta kendi dolaşacak. Bu dolaşma 30 saniye olursa her katta 40 saniye kaybeder." demiştir. Mert ise "Ĕger otoparkta ışık sistemi yoksa nasıl boş yerde kırmızı ışık yanıp yanmadığına gözümüzü gezdiriyorsak ışık sistemi olmadı̆̆ında da yine göz gezdireceğiz ama bu sefer ışık sistemindeki gibi 
yerin boş mu dolu mu olup olmadı̆̆ını bilemeyeceğiz. Bu bizim açımızdan daha uzun bir zaman geçireceğimiz anlamına gelir. Yani bu da demek oluyor ki süremiz 20 ila 25 saniye arasında değişir. Ve ben bu süreye 25 saniye demek istiyorum." demiştir. Tüm bu katılımcıların ifadeleri gözden geçirildiğinde akıl yürütme becerileri düşünüldüğünde informal matematiksel argüman oluşturup değerlendirme yapabildiği (AY 2) görülmektedir.

Oturum sonunda katılımcıların robotik kodlama sürecinde günlük yaşam durumunu değerlendirme, problem durumu için yazılacak kod düşünme, yazılacak kodu düşünürken problem durumunun içindeki örüntüyü keşfedip genellemeye varma süreçlerinin gözlemlendiği ancak aşama kaydedilmesi gerektiği görülmüştür. Kodlamanın fiziksel hali olan robotlar, katılımcılarımızın problem durumunun zihinlerinde somutlaşmasında katkı sunmuş, denklemin ne anlama geldiği konusunda, yazılan denklemlerin günlük yaşama aktarılmasında yeni bir pencere olması açısından da katılımcıların dikkatini çekti, matematiksel argüman üretmeye yardımcı oldu denebilir.

\subsubsection{II. Öğretim Deneyi Oturumunun Bulgularl}

İkinci oturumda ise bir bebeğin duvara olan uzaklığ $40 \mathrm{~cm}$, şömineye olan uzaklığı $100 \mathrm{~cm}$ 'dir. Emeklemeye yeni başlamış olan Erdem dakikada $10 \mathrm{~cm}$ yol alabiliyor ve şömine yanıkken sensör devreye girip Erdem bebeğin şömineye ulaşmasına $20 \mathrm{~cm}$ kala ötmekte ve ebeveynlerin duruma müdahale etme şansı olmaktadır. Bu durumu sağlayacak algoritmayı yazmaları gruplardan beklenmiştir.

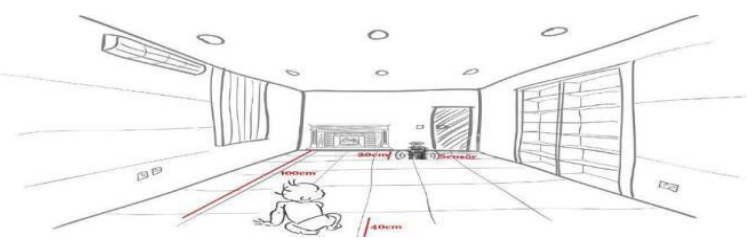

Şekil 6. II. Öğretim deneyi için oluşturulan senaryonun görseli

Grup 3 elemanları Asya ve Emre'in algoritmasına Şekil 7'de bakıldığında şöminenin yanıp yanmamasına dikkat ettikleri ancak bebeğin şömineye ulaşmasına $20 \mathrm{~cm}$ kala sensörün devreye girebilmesi için mesafe sensörüne dikkat edilmemiştir. Dolayısıyla problemi analiz ederken değişkenler eksik analiz edilmiş hatta ikinci dallanmada mesafe sensörü yerine hareket sensörü seçilerek yanlış sensör kullanılmıştır. Kodun bu kısmını yazma sürecinde grup; matematiksel argümanlar oluşturmuş, bu argürmanlar doğrultusunda değerlendirme yapmış (AY2), problem durumunu analiz etmiş ve değerlendirme yapmıştır (AY3). Yazdıkları kodu "bağla" komutu ile başa bağlamış olmaları sensörün bu görevi sürekli yerine getirmesi gerektiğinin farkında olduklarının yani örüntüyü görebildiklerini gösterir. Bu durum da genellemeleri değerlendirebilmiş (AY1), matematiksel ilişkiyi farketmiş tümevarımsal akıl yürütmeyi (AY4) kullanmıştır. Benzer bulgular Grup 1 ve Grup 2'nin algoritmalarında da görülmüştür.

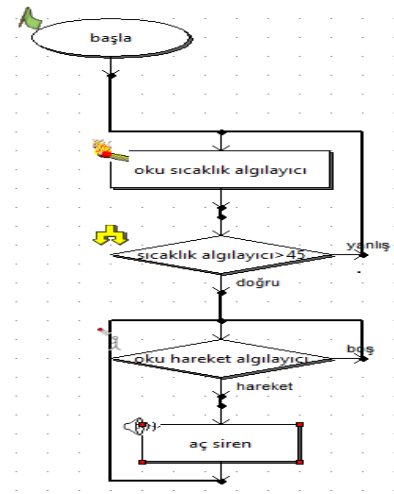

Şekil 7. Grup 3'ün Yazdığı Algoritma

$\mathrm{Bu}$ kısımdan sonra oturumun devamında dakikada $10 \mathrm{~cm}$ emekleyebilen Erdem bebeğin şömineye emekleyerek doğrusal yaklaşmasıyla aldığı yolun ilk 5 dakikasındaki tablosu ve denklemi, aynı durumun Erdem bebeğin arkasındaki duvardan uzaklaşmasına ait tablo ve denklemini bireysel olarak cevaplamaları istenmiştir. Ardından katılımcılarda göstergelerin daha derinlemesine incelenmesi ve anlaşılabilmesi için oturumda Erdem bebek ilk olarak dakikada $10 \mathrm{~cm}$ hızla emeklemesini dakikada $15 \mathrm{~cm}$ hıza çıkarılmıştır. Emekleme hızındaki bu değişim doğrusal denklemi, şömine önündeki sensörün yerinin nasıl değişeceği konusunda sorular sorulmuştur. Öğrencilerden Su'nun çözümü Şekil 8'de verilmiştir. 


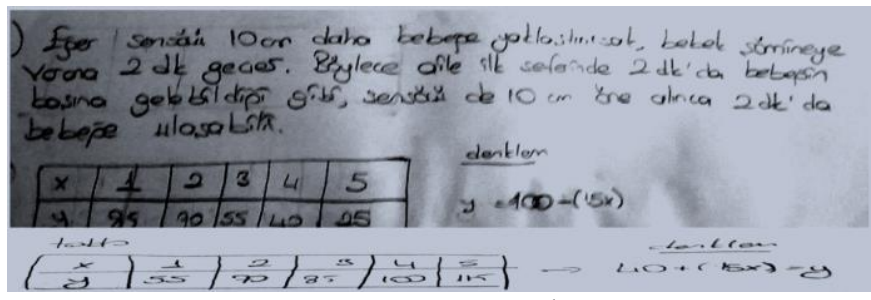

Şekil 8. Su'nun Cevabı

Şekil 8'de de görüldüğü gibi Su, bebeğin emekleme hızının artışıyla birlikte dakikada alacağı yolu ifade ederken tablo ve informal matematiksel açıklamalardan faydalanarak problemi çözmüş (AY3), tümevarımsal matematiksel bir ilişki keşfetmiş (AY4) ve bunu doğrusal denkleme dönüştürmüştür. Benzer şekilde aşağıda yansıtılan grup içi tartışmada da katılımcıların kendilerini ifade etmede sayısal verileri kullanma, matematiksel ilişkiyi kullanma (AY4) eğiliminde oldukları görülmektedir.

Araştırmacı: Erdem bebeğin emekleme hızının değişmesinde değişecek durumları dĕ̆erlendirirken dilerseniz önce algoritma değişir mi, değişirse nasıl, ardından denklemin nasıl değişeceğini tartışalım.

Su: Önce ilk durumu konuşmalıyız. Baktığımızda ilk durumda sensör şöminenin $20 \mathrm{~cm}$ önünde Erdem ise dakikada $10 \mathrm{~cm}$ yol alıyor. Bunun arasında mantıklı bir ilişki var.

Ilgaz : Ve aynı zamanda sensöre $20 \mathrm{~cm}$ yaklaştı̆̆ında da sensör ötüyor. Burada da..

Asya: Bakıldığında bebek ile şömine arasında $40 \mathrm{~cm}$ varken ilk uyarı sensörden geliyor. Yani 4 dakikası olur ebeveynlerin bu durumda. (AY2)

Eren: Yeni durumda 2 dakika 40 saniyesi olacak ebeveynlerin (AY3)

Emre: Yeterli bir süre.

Mert: Sorudaki durumu düzenlersek bence sensörün yeni yeri şömineye $30 \mathrm{~cm}$ uzaklıkta olmall.

Asya: Hatta yeni yazllan kodda da Erdem sensöre $30 \mathrm{~cm}$ kala uyarmalı. (AY4)

Su: Başlangıçta 4 dakika zaman kazanıyordu ebeveynler, dolayısıyla yeniden bu zamanı kazanacak şekilde sensör ve denklem değişmeli.

Emre: Bence 4 dakika çok uzun ben küçük bir ses duysam bebeğin yalnız olduğu odadan oraya koşarak giderim. Ben sensörün yerini de algoritmayı da değiştirmeyeceğim. (AY6)

Buraya kadar ki konuşmalardan tartışmanın informal matematiksel argüman oluşturma, değerlendirme ve destekleme (AY2) gelişimine ve ilgili genellemeye varma sürecinde problemi analiz edip değerlendirme (AY3), yine kendi aralarında konuşmalar esnasında sorunun içinde ebeveyne tanınan süreyi yeni durumda da koruyabileceği matematiksel ilişkiyi (AY4) kurmaya yönelik gelişim gözlenmiştir. Ayrıca Emre son söylediği ile olası tartışmayı arttırmaya (AY6) yönlendirmiş ve şu şekilde devam etmiştir.

Araştırmacı: Sizce mantıklı olan neyse soruyu ona göre yanıtlayabilirsiniz, kağıtlarınıza bunu yansıtmanız yeterli.

Eren: Aslında Emre'nin söylediği mantıklı, sonuçta 2 dakika 40 saniye de çok yeterli bir süre.

Ilgaz : Bence sorunun başlangıçta kuruluş mantı̆̆ına göre yazmalıyız. (AY6)

Araştırmacı: Dediğim gibi sizin için nasıl mantıklıysa ona göre yanıt vermeniz ve sebebini açıklamanız yeterli. Bu arada Erdem 'in daha hızlı emeklemesi sadece sensörü mü etkiler?

...Sessizlik...

Mert: Benim kafam karıştı.

Asya : Benim de

$\mathrm{Su}:$ Neden? (AY6)

Mert: Sensörün yerinin değişmesi etkiler mi denklemi?...(Sessizlik)

Araştırmacı: Denklemin değişkenleri ve algoritmanın değişkenleri nelerdir? diye sorsam.

Emre : Algoritmaninkiler sicaklık ve mesafe...

Araştırmacı: Hem fikir miyiz?

Asya : Biz bunu Emre'yle kodu yazarken tartıştık, şimdi şömine yanıyorken bebek sensöre doğru hareket ederse ve hatta $20 \mathrm{~cm}$ kala itibaren sensörün siren çalmasını istiyoruz. Dolayıslyla iki sensör tanımladık sicaklik ve mesafe.

Ilgaz : Biz eksik yapmışız. (AY5)

Eren : Biz de.

Araştırmacı: Peki, Emre ve Asya'nın değişkenlerini doğru buldunuz mu?

E,I,S,M : Evet.

Araştırmac1: Peki denklemin değişkenleri nelerdir?

$\mathrm{Su}$ : Erdem bebeğin emekleme hızına bă̆ll olarak aldı̆̆ yolun denklemini yazıyoruz. Dolayısıyla Erdem'in emekleme hizl ve yol.

Mert : Doğru. 
Eren : Ben yine de anlayamadım.

Araştırmacı: Tabloyu yazmakla başlasanız?

$\mathrm{Bu}$ kısımda ise yapılacak tartışmada başkalarının düşüncelerini anlamlandırma ve arkasındaki mantığı anlama (AY5); tartışmalar esnasında olası yanlış anlama ya da anlaşmazlıkta sorular sorup tartışmayı arttırma (AY6) kriterlerinde gelişim gözlenmektedir. Bu tartışma sürecinin ardından bebeğin emekleme hızının değişmesiyle sensörün nereye konulması, nasıl bir algoritma ve doğrusal denklem yasılması gerektiği sorulmuştur. Yanıtlar incelendiğinde dikkati çeken bir durum ise katılımcıların birbirlerinden çok farklı ancak aynı anlama gelecek şekilde ifade etmeleridir. Bu durum Tablo 5'te gösterilmektedir.

Tablo 5. Katılımciların yanitları

\begin{tabular}{|c|c|}
\hline Katılımeı & Emekleme Hızının Değişmesiyle Sensör Üzerine Verilen Yanıtlar \\
\hline Ilgaz & $\begin{array}{l}\text { Erdem bebeğin emekleme hızının artmasıyla sensör algılama mesafesini arttırma yani algoritmayı } \\
\text { değiştirme ancak sensörün yeri aynı kalması }\end{array}$ \\
\hline Eren & $\begin{array}{l}\text { Erdem bebeğin emekleme hızının artmasıyla sensör yerinin değiştirmede şömineden uzaklaşma değil } \\
\text { duvara yaklaşma ifadesi kullanması }\end{array}$ \\
\hline $\mathrm{Su}$ & Erdem bebeğin emekleme hızının artmasıyla sensörü bebeğe yaklaştırmak ifadesi kullanması \\
\hline Mert & $\begin{array}{l}\text { Erdem bebeğin emekleme hızının artmasıyla sensörün yerini şömineden } 30 \mathrm{~cm} \text { uzaklaştırma gibi bir } \\
\text { açıklama }\end{array}$ \\
\hline Asya & Erdem bebeğin emekleme hızının artmasıyla sensörü şömineden uzaklaştırma makul bir açıklama \\
\hline Emre & $\begin{array}{l}\text { "Bence } 4 \text { dakika çok uzun ben küçük bir ses duysam bebeğin yalnı olduğu odaya koşarak giderim. } \\
\text { Ben sensörün yerini de algoritmayl da değiștirmeyeceğim." diyerek açılama yapması }\end{array}$ \\
\hline
\end{tabular}

$\mathrm{Bu}$ oturumun genel bir değerlendirmesini yapmak gerekirse grupların hala yeterli algoritma yazamadıkları ancak doğrusal denklem yazımı ve diğer temsil biçimleri ile ifade etme gelişimin genel olarak gözlendiği söylenebilir. Akıl yürütme becerilerinden AY5 ve AY6'nın gözlenebilmesi açısından yukarıda yansıtılan tartışma yürütülmüş bu tartışmada her bir katılımcının akran baskı hissetmeden kendini anladıkları ya da anlamadıkları yerler üzerinden ifade edebilmiş, birbirlerinin anlamlandırmalarına katkı sunmuşlardır. En ilginç olanı ise her birinin bu tartışmadan önce, algoritmanın ve denklemin birbirinden farklı değişkenlerinin bebeğin emekleme hızına göre nasıl değişeceği ile ilgili tam bir fikirlerinin olmamasıdır. Yine dikkat çekici bir durum ise katılımcıların tüm tartışma süreci bitip ardından kâğıtlarında soruları yanıtlarken soruları yanıtlamaya geçtiklerinde Tablo 5'te görüldüğü üzere kendi cümleleriyle informal matematiksel açıklamalarla birbirinden farklı ifadelerle doğruya ulaşmışlardır. Bu sebeple katılımcılarda AY7 gelişimi gözlenmektedir. Bir de algoritma yazma, yazdıkları algoritmayı robot üzerinde denemenin ve sessizlik anlarında akıl yürütmelerinin etkisiyle tartışma sonunda verilen yanıtların kimi küçük hatalar dışında kabul edilebilir ve birbirinden farklı yorumları barındırdığı söylenebilir.

\subsubsection{III. Öğretim Deneyi Bulgulart}

$\mathrm{Bu}$ oturumda ilk iki oturumdan deneyimle akıl yürütme kriterlerinin gelişiminin arttırılması, algoritma yazımında eksik kalan grupların kendini biraz daha geliştirmesi ve birbirlerinden öğrenirken birbirlerini baskılamamaları sorgulamayı sürdürmeleri nedeniyle altı kişinin tartışarak bir algoritma yazması istenmiştir. 10 saniyelik algoritmayı üç robota da yükleyip bir koreografi oluşturmaları beklenmiştir. Bulgular incelenirken ilk önce grupların algoritmaları ve bu algoritmaları yazarken gözlenen cebirsel akıl yürütme kriterleri incelenmiş, ardından sorulara bireysel olarak verdikleri yanıtlar kriterler çatısında her bir katılımeı için ayrı yorumlanmıştır. Tüm katılımcılar bu zamana kadar öğrendikleri kod yazma becerileriyle tek bir algoritma üzerine tartışmıştır. Bu süreçte "başkalarının düşüncelerini anlamlandırma ve arkasındaki mantığı kavrama (AY5), fikir alışverişi esnasında olası yanlış anlama/anlaşmazlık durumunda soru sorup tartışmayı derinleştirme (AY6) göstergelerinin bir kez daha gözleme imkanı da olmuştur. Bu durum aşağıda verilen konuşmalarda da görülmektedir.

Araştırmacı: Dilediğiniz gibi bir algoritma yazabilirsiniz, kendi etrafinda dönen, düz devam eden, 1 sn bekleyip 3 sn ilerleyen. Şu ana kadar öğrenilen tüm sensörleri de devreye sokabilirsiniz, nasıl isterseniz.

Su : Robotlar kare dönerse eş zamanl güzel bir koreografi olur.

Eren : Daha farklı da olabilir.

Ilgaz : Beşgen, altıgen denenebilir de çok zor olur.

$\mathrm{Su}: 108^{\circ}$ lik dönme açısı ile olur aslında.

Araştırmacı : Neden zor olur?

Ilgaz : Denklemini yazması zor bence. (AY6)

Mert : Kare olsun. Bir de kenarlarına kalem bağlayalım, çizimle de göstersin karesel şekil etrafinda gittiğini. (AY6)

Emre : Kalem güzel olabilir ama zeminin durumu robotların sürtünmesini arttırır. Pil ömrü nedeniyle bile simülasyonda gösterdiği hassaslıkta gidemediğini görüyoruz uygulamalarımızda, işimizi zorlaştırır. (AY5) 
...(Grup düşünür ikna olduktan sonra)...

Asya : Kare yapmaya karar verdiysek algoritmamızı yazalım. (AY5)

Ilgaz : Aslında iç içe çemberler oluşturacak şekilde bir algoritma yazsak mı, çok güzel görünür.

Asya : Evet.

Emre : Ama onun denklemini yazmak çok zor.

Ilgaz : Çok doğru. Kare iyidir.

Katılımcıların kendi aralarında yürüttükleri tartışmada Mert ve Emre robotun aldığı yolun dışarıdan daha iyi algılanması kalem kullanılması durmunu konuşmuşlar ve bu durumun sürtünmeden dolayı zor olabileceği fikrinde anlaşmışlardır. Burada öğrencilerin diğer derslerden öğrendikleri bilgileri de birleştirerek bu durumun olamayacağı mantığını açıklayarak arkadaşlarını ikna etmiştir. Ayrıca burada karenin bir iç açı ölçüsünden faydalanarak algoritma yazan katılımcıların düzgün beşgensel bölge etrafında hareket edecek robot için $108^{0}$ 'nin ifade edilmesinin kodlama yaparken temel geometri bilgilerini işe koşmalarının gerekliliğini de ortaya koymuştur. Bununla birlikte basit bir algoritma yazma konusunda anlaştıkları gözlemlendi. Nedeni sorulduğunda "basit bir algoritmayı uygulayan robotlar gözlemesi, uygulaması dolayısıla denkleminin ve grafiğinin yazımının da daha kolay olacağ konusunda hem fikir olmaları” olduğunu belirttiler. Yapılan tartışmalarda bahsedilen kodlar basit değildir ancak denklem yazmaktan çekinip kod yazmaktan çekinmemeleri de üzerine düşünülmesi gereken bir noktadır.

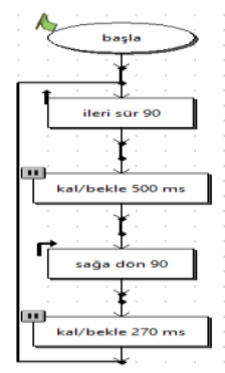

Bir Arada Yazilan tlk Algoritm

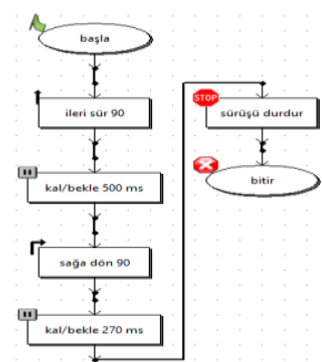

Bir Arada Yazilan tkinci Algoritu

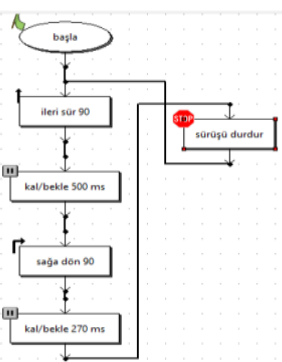

Bir Arada Yazılan Üẹüncủ Algoritma

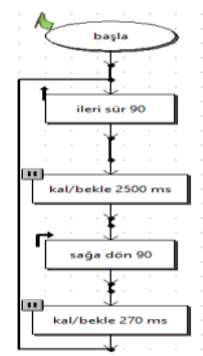

Bir Arada Yazilan Son Algoritma

Şekil 7. III. Oturum için yazılan algoritma

Şekil 7'den de görüldüğü üzere oluşturdukları ilk algoritmada $500 \mathrm{~ms}$ boyunca düz giden $\operatorname{ardından~} 90^{\circ}$ dönen ardından bunu yeniden tekrarlayan dolayısıyla karesel bir şekil etrafinda dönen bir robot algoritması yazdıkları görülmektedir. İkinci algoritmada robotun biraz duraksamasını istediklerini belirtmişler, ancak yazdıkları kodun anlamı $500 \mathrm{~ms}$ boyunca düz giden ardından $90^{\circ}$ derece dönüp duran robot olduğunu simülasyonda görünce yazdıkları kodun istedikleri gibi olmadığını fark etmişlerdir. Üçüncü algoritmadaki revize de eksik bir revize olmuştur. Simülasyonda yine istediklerine ulaşamadıklarını görünce son revize gerçekleşmiştir. Son algoritma aslında ilk yazdıklarına çok benzer durumdadır. Tek farkı kendi söylemleriyle gözlemesi daha kolay olacak biçimde $2500 \mathrm{~ms}$ boyunca düz giden robot ardından $90^{\circ}$ derece dönecektir. $2500 \mathrm{~ms}$ seçilmesinde ise 10 saniyelik hareketi tamamlamanın baz alındığı diyaloglarında gözlenmiştir.

Sonuç olarak öğretim deneylerinde robota algoritma yükleme, yüklenen kodların gözlenmesi, gözlenen durumların tabloya, sayı örüntüsüne, sözel genellemeye ve denkleme dönüştürülmesinin beklenmiş ve katılımcıların bu durumları yansıttıkları görülmüştür ki bunun çoklu temsilleri kullanma ve birbirine dönüştürmeye katkı sunduğu açıktır.

\subsection{Son Test Sorularının Bulguları}

Son testte bir işveren mutfağında çalıştıracak mutfak personeli için iki aşçıyı deneme sürecine almış, bu iki aşçının günlük çalışma performanslarının hazırlık süresine bağlı tabak sayısı grafiğe verilmiştir. Ardından katılımcılardan bu grafiğe yönelik tablo ve sıralı ikili yazma, sözel genelleme kurma, hazırlama süresine bağlı hazırlanacak tabağın denklemini yazma, hangi aşçının daha hızlı olduğuna karar verme ve hangi aşçıyı işe almak gerektiğine dair karar vermesi istenmiştir. Son testte verilen yanıtlar doğrultusunda temalar halinde incelenmiştir. Son test analizleri Tablo 6'da verilmiştir. 
Tablo 6. Öğrencilerin sontest sonucundaki durumları

\begin{tabular}{|c|c|c|c|c|c|c|c|}
\hline Tema & Alt Tema & Eren & Ilgaz & Mert & Su & Asya & Emre \\
\hline \multirow{4}{*}{$\begin{array}{l}\text { Genellemeleri Formüle } \\
\text { Etme Destekleme/ } \\
\text { Değerlendirme } \\
\text { AY1 }\end{array}$} & Doğrusal Denklem & Doğru & Doğru & Doğru & Doğru & Doğru & Doğru \\
\hline & Yazma & & & & & & \\
\hline & Genellemeleri & Doğru & Doğru & Doğru & Doğru & Doğru & Doğru \\
\hline & Destekleme/ & & & & & & \\
\hline \multirow{3}{*}{$\begin{array}{c}\text { Matematiksel Argüman } \\
\text { Oluşturma } \\
\text { AY2 }\end{array}$} & $\Gamma_{0}+1$ & $\mathrm{Y}$ & $\mathrm{Vel}$ & $\mathrm{Yg}$ & $\mathrm{Y}$ & $\mathrm{Y}$. & Kismen $>$ \\
\hline & Formal Açıklama & Yok & Yok & YOK & Yok & Yok & Doğru \\
\hline & İnformal Açıklama & Doğru & Doğru & Doğru & Doğru & Doğru & Doğru \\
\hline \multirow{3}{*}{$\begin{array}{c}\text { Problem Durumunu } \\
\text { Analiz Etme } \\
\text { AY3 }\end{array}$} & Problemi Anlama & Doğru & Doğru & Doğru & Doğru & Kismen & Doğru \\
\hline & & & & & & Doğru & \\
\hline & Problemi Çözebilme & Doğru & Doğru & Doğru & Doğru & Doğru & Doğru \\
\hline \multirow{3}{*}{$\begin{array}{c}\text { Matematiksel İlişki } \\
\text { Kurmak } \\
\text { AY4 }\end{array}$} & Tümevarımsal İlişki & Doğru & Doğru & Kismen & Doğru & Kismen & Doğru \\
\hline & & & & & & Doğru & \\
\hline & Tümdengelimsel İlişki & Doğru & Doğru & Doğru & Doğru & Doğru & Doğru \\
\hline \multicolumn{2}{|c|}{ Çeşitli Sonuçlardaki Sonuçları Doğrulama AY7 } & Yok & Doğru & Yok & Doğru & $\begin{array}{c}\text { Kısmen } \\
\text { Doğru }\end{array}$ & Doğru \\
\hline
\end{tabular}

Bu tabloya göre doğrusal denklem yazabildikleri ve genellemeleri desteklemeyi sayı örüntüsüyle ve sözel genellemelerle gerçekleştirebildikleri görülmüştür. Matematiksel argüman oluşturma temasına bakıldığında yine yanitlar informal argümanlarla desteklenmiş ve bu bölümde de yanitlayan katılımcı sayısına da ön teste göre daha doğru argüman kurdukları gözlenmiştir. İnformal açıklamada gelişimin olmasında robotik kodlama sürecinin ve birbirleriyle oluşturdukları tartışma süreçlerinin etkisi olmuş olabilir. Ancak matematiksel durumlara dair argüman geliştirebilmenin gelişiminin matematiksel anlamaya da cebirsel akıl yürütmeye de katkı sunduğu ulaşılan noktada açıktır. Problem durumunu analiz etme temasında problemi anlama ve çözme durumları ön teste göre bir adım daha iyi durumdırlar denilebilir. Ön testte problem durumunu analiz etmede sorun yaşayan katılımcıların son testte rahatlıkla problem durumunu analiz edebildiği, problem durumunu açıklamada temsil biçimi kullandıkları gözlenmiştir. Bunda birbirinden farklı problem durumlarıyla karşılaşma ve bu problemlere kod yazarken birlikte, ardından kendi kendilerine yanıt üretmeye çalışmalarının katkısı olduğu düşünülmektedir. Matematiksel ilişsi kurmada yine informal yönelim oldukça fazla olup doğru yanitta artı̧̧ görünmektedir. Matematiksel ilişski kurmada tümevarımsal ve tümdengelimsel ilişki biçimlerinin kullanımının arttı̆̆ı görülmektedir. Ancak çeşitli konulardaki sonuçları doğrulama ön testteki gibi oldukça sınırlı kalmış, bir gelişim gözlenmemiş̧ir.

\section{Sonuç, Tartışma ve Öneriler}

Bu çalışmada cebir alt öğrenme alanında yer alan doğrusal denklemler konusunda cebirsel akıl yürütmenin gelişim sürecinin incelenmesi amaçlanmıştır. Katılımcıların gelişimleri Tablo 1'de cebirsel akıl yürütme göstergeleri olarak verilen temalar (genellemeleri formüle etme, matematiksel argüman oluş̧urma, problem durumunu analiz etme, matematiksel ilişki kurma, çeşitli konulardaki sonuçları doğrulama) dikkate alınarak incelenmiş̧ir.

İlk olarak "Genellemeleri formüle etme" temasında elde edilen sonuçlar öntest, öğretim deneyi süreci ve son test göz önüne alınarak sunulmuştur. Genellemeleri formüle ederken ön testte öğrencilerden bir doğru bir şekilde denklem kurabilirken diğer öğrencilerin $y=a x$ veya $y=a x+b$ formatında doğrusal denklemi kurmakta zorlandıkları görülmüştür. Öğretim deneyleri boyunca grup elemanları beraber algoritmayı oluşturma çabasında bulundukları süreçte bazı grupların dikdörtgenin karşılıklı kenar uzunlukları ve katlar arası yol uzunlukları arasındaki örüntüyü fark edip genellemeleri oluşturduğu görülmüştür. Ayrıca diğer öğretim deneyinde de bazı grupların yol ve zaman arasındaki ilişkiyi denklem ile belirtebildiği saptanmıştır. Öğretim deneyi sürecinde öğrencilerin senayolar kapsamında gözlenen durumları tabloya, sayı örüntürüne, sözel genellemeye ve denkleme dönüştürdükleri gözlenmiştir. $\mathrm{Bu}$ noktada çalı̧şmada öğretim deneyi sonunda uygulanan son testte tüm katılımcıların tüm genellemeleri doğru formüle edebildikleri, değişkenler arasındaki ilişkiyi kurabildikleri ve denkleme dönüştürdükleri sonucuna varılmıştır. Ancak öğrencilerin dikdörtgenin kenar uzunlukları ve katlar aras1 yolu cebirsel ifadeye yansitabildikleri sonucu Atasoy ve Bulut (2018) ile Dindyal'ın (2004) yaptıklar1 çalş̧malarda öğrencilerin geometrik ş̧ekillerin özelliklerindeki değişim ile cebirsel ifadedeki değişimi yorumlamada zorlandıkları sonucu ile örtüşmemektedir. Kodlama sürecinde kodladıkları algoritmaları, simülasyonda izlemeleri ile bu durumu denemiş olmalarının faydası olmuş olabilir. Sonuç olarak bu araştırma 
kapsamında katılımcıların genellemeleri formüle edebilmeleri kodlama sürecinde cebirsel ifadeleri kullanmalarına yardımcı olmuştur denilebilir. Bir yandan da gelecekteki çalışmalarda, katılımcıların cebirsel akıl yürütmelerinin yanı sıra, kodlamayla birlikte cebirsel düşünme düzeylerinde ki gelişim incelenebilir. Bir de yapılan çalışmada genellemeleri formüle etme ve bu temsillerin ne anlama geldiğini anlamlandırma sürecinde gelişimden yola çıkarak kodlama eğitimleri ülkemizde ve dünyada anasınıfı düzeyinde başlamaktadır. Dolayısıyla eğitsel robotik uygulamaları diğer sınıf düzeylerinde bulunan cebir öğrenme alanlarında da yaprlabilir.

"Matematiksel argüman oluşturma" temasında öğrenciler ön testte sorulara cevap verirken argümanları informal olarak kısmen de olsa yansıtabilmişlerdir. Öğretim deneyleri boyunca katılımcıların sayı örüntüsü, tablo yazma, denklem oluşturma ve grup içi ve tüm katılımcılarla tartışmalar yürüterek matematiksel argüman oluşturmaya çalıştıkları gözlenmiştir. Argümantasyon yoluyla grup içi tartışmaların farklı düşünme ve sorgulama yollarını ortaya koyması sebebiyle matematiksel fikirler analiz edilebilir ve geometrik kavram bilgi ve anlayışında gelişim gösterdiği görülmüştür (Uygun ve Akyüz, 2019). Benzer şekilde çalışmamızda da katılımcıların grup içi ve toplu tartışma ortamında matematiksel dili kullanarak argümanlar (Yackel ve Cobb, 1994) üretmiş, böylelikle doğrusal denklemler konusuna yönelik bilgilerinde artış görülmüştür. Öğretim deneyleri sonunda uygulanan son testte tüm katılımcıların doğru informal açıklamalar yaparak matematiksel argüman oluşturduğu görülmüştür. $\mathrm{Bu}$ bağlamda çalışma kapsamındaki öğrenciler eğitsel robotik uygulamalarında kodlama yaparken matematiksel argüman oluşturabilmektedir sonucu söylenebilir.

"Problem durumunu analiz etme" temasında katılımcılar problem durumunda verilen yararlı bilgilerden faydalandıkları ve çoklu temsil biçimlerini birbirine dönüştürdükleri görülmüştür. Silik'in (2016) de belirttiği gibi robotik uygulamalarda öğrencilerin yaparak yaşayarak öğrenme, problem çözme, problemlere pratik çözümler bulma, eleştirel düşünme, kendi yeteneklerinin farkına varma, kullanma düzeylerinde artma ve teknoloji kullanmaya daha istekli olma gibi birçok beceriyi kazandıkları görülmüştür. Çalışmamızın bu sonucunun Silik'in ifade ettiği durumlarla örtüştüğü söylenebilir.

"Matematiksel ilişki kurma" temasında katılımcılar ön testte matematiksel ilişkileri kurmayı kısmen de olsa yansıtabilmişlerdir. Özellikle katılımcılardan bazırlarının eksen üzerindeki noktaların eşit aralıklı olmalarını dikkate almadıkları saptanmıştır. Bu durum Gürbüz ve Şahin'in (2015) 8. sınıf öğrencilerinin çoklu temsiller arasındaki geçişleri inceledikleri çalışmada, öğrencilerin birimler arasındaki uzaklıklara dikkat etmediği ve sayıları yerleştirdikleri sonucuyla örtüşmektedir. Öğretim deneyleri boyunca özellikle son öğretim deneyi oturumunda katılımcılar geometri bilgileriyle kod yazma durumlarını ilişkilendirerek bir karar verme gerçekleştirmişler ve matematiksel ilişkileri rahatlıkla kurabilmişlerdir. Katılımcıların dikdörtgensel şekil etrafinda dönmek için $90^{\circ}$ dönülmesi ve robotun dikdörtgenin kenar uzunlukları oranında etrafinda yol alacağını bilerek kod yazmaları gerektiğini fark etmişlerdir. Son testte de çoğu öğrencinin problem durumlarını günlük yaşamla ilişkilendirdiği, grafik temsilden yola çıkarak tablo değerlerini oluşturabildikleri, grafik temsilden cebirsel ifadeye geçişin öğrencilerin yarısı tarafından gerçekleştirildiği belirlenmiştir. Bu bulgu, öğrencilerin grafik temsilden yola çıkarak denklem oluşturmakta zorlandıklarını belirten (Knuth, 2000; Tekay ve Doğan, 2015) çalışmalarla örtüşmemektedir. Ayrıca katılımcılar süreçte yaptıkları algoritma denemelerini simülasyon ile gerçek yaşam arasında ilişkilendirme yaptıkları saptanmıştır. Sonuç olarak eğitsel robotik uygulamalarının günlük yaşam ve konular arası ilişkilendirme sürecine olumlu katkısı olduğu söylenebilir. Buradan yola çıkarak gelecek çalışmalarda eğitsel robotik uygulamaları öğretim programlarında yer alan farklı konular ve öğrenme alanlarında yapılarak öğrenme çıktıları araştırılabilir. Örneğin robotun belirli açıyla dönmesi üzerine konuşulurken açı değerlerinin konuşulması, geometri alanında çokgenler konusunda çalışmaların yapılabileceğinin önemli bir göstergesidir. Bunun dışında çalışmamızda cebir konu alanında bulunan doğrusal denklemler konusuyla geometri bilgilerinin ilişkilendirildiği görülmüştür. Eğitsel robotik uygulamalarının konular arası ilişkilendirmeye katkısı da incelenebilir.

Cebirsel akıl yürütme göstergelerinden AY5 "Başkalarının düşüncelerini/fikirlerini/ yaklaşımlarını anlamlandırma ve bunların arkasındaki mantı̆̆ı sağlama" ve AY6 "Yanlış anlama ya da anlaşmazlık durumlarında sorular sorma ve tartışmayı arttırma" göstergeleri tematik analizde gerek ön testte gerek son testte ele alınmamıştır. Çünkü bu göstergeler kişiler arası iletişimle gözlenebilecek ve gelişimine dair yorum yapılabilecek göstergelerdir. Sfard (2007), öğrenmenin iletişimde bir değişiklik olduğunu ifade etmiş ve matematiksel öğrenmeyi tanımlamak için ortak bir çerçeve önermiştir. Başka bir deyişle, bir öğrencinin matematik öğrenimi, matematik hakkında konuşmak için kullandıkları dili gözlemleyerek değerlendirilebilir. Bu göstergenin oturumlar sürecinde gelişimine bakıldığında, ilk oturumlarda bu etkileşim daha az iken II. oturumda gerçekleşen değişken kavramı üzerine tartışma, III. oturumda da yazılacak ortak algoritma üzerine tartışmalarda gelişim gösterdiği açıktır. Katılımcıların matematiği, özelinde doğrusal denklemler konusunu, anlamlandırma süreçlerinde matematiksel düşünmelerini görünür kılan matematiksel iletişim kurmaları bir süreç becerisi (Kabael ve Ata-Baran, 2016) olmakla birlikte, matematiksel problem durumlarını çözme ve gerekçelendirmede çözüm sürecini içeren argümanlarını yazılı ve sözlü bir biçimde ortaya koymadır (Organisation for Economic Co-operation and Development [OECD], 2013). Katılımcıların oturumlar süresince bu eylemler içerisinde 
bulunduğu görülmektedir. Akran iletişimi matematiksel dil gelişimine katkı sunar (Pellegini ve ark., 1997) ancak, dil gelişimi için tek başına yeterli değildir (Topping ve ark., 2004) bunun için iletişimin yanı sıra akran etkileşimi de önerilmektedir (Hoff, 2006). Steffe'ye (1991) göre matematiksel bir kavram olarak Yakınsak Gelişim Alanı, yapılandırmacı bir öğrenme ortamında etkileşim neticesinde ortaya çıkar. Daha yetkin veya yetişkin birey ile olan etkileşimdeki matematiksel fikir alışverişi neticesinde, öğrenen birey mevcut matematiksel bilgisini yeniden yapılandırır. Bu yapılandırma süreci iki düzey arasındaki farkın kapanmasını sağlar (Pritchard ve Woollard, 2010). Çalışmada da üç katılımcının akademik anlamda orta, üçünün iyi olması; kimi katılımcıların daha önceden farklı robotik kodlama programları biliyor olması bu gelişime katkı sunduğu saptanmıştır. Bunun yanında oturumlardaki diyalogların başkalarının fikirlerini anlamlandırma, yanlış anlaşmazlık durumunda tartışmayı arttırma kriterlerine katkı sağladığı açıktır. Bu nedenle bu öğretim deneyi sürecinin cebirsel akıl yürütme gelişimine katkı sağladığı söylenebilir.

"Çeşitli konulardaki sonuçları doğrulama" temasında katılımcılar beklenen düzeyde gelişim göstermediği söylenebilir. Öğretim deneylerinde kullanılan açık uçlu soruların son kısmı verilen senaryolarda bulunan değişkenlerin değişimi ve bu değişimin sorunun cevaplarını nasıl etkileyeceğine yöneliktir. Gerek bu yanıtların bireysel yanıtlanan kısımlar olması gerekse de gerçekleştirilen öğretim deneyi oturum sayısı yetersiz kalmış olabilir. Yine bu çalışmanın 7. sınıf doğrusal denklemler konusunun öğretim programında dikkat çekilen bölümlerine odaklanılmış olması ve ders saati sınırlamasının öğretim deneyi sayısını sınırlaması da bu temada gerekli gelişimi görememeye neden olmuş olabilir. İleride yapılacak çalışmalarda akıl yürütme göstergesi olarak bu gösterge üzerine yoğunlaşılabilir. Yine bu bir yandan da doğaları gereği çeşitli bakış açıları geliştirebilen üstün yetenekli öğrencilerin birden fazla disiplinlerle ilişkilendirilmiş zengin öğrenme ortamlarına daha çok ihtiyaç duydukları göz önünde bulundurulduğunda, eğitsel robotik uygulamalarının üstün yetenekli bireylerde etkisi incelenebilir. Bu tema açısından yine daha zengin yorum elde edilebileceği düşünülmektedir.

\section{Kaynaklar / References}

Akgündüz, D., Aydeniz, M., Çakmakçı, G., Çavaş, B., Çorlu, M. S., Öner, T. ve Özdemir, S. (2015). STEM eğitimi Türkiye raporu. İstanbul: Scala Basım.

Aksu, F. N. (2019). Bilişim teknolojileri öğretmenleri gözünden robotik kodlama ve robotik yarışmaları (Yayımlanmamış yüksek lisans tezi). Balıkesir Üniversitesi, Fen Bilimleri Enstitüsü, Balıkesir.

Alfieri, L., Higashi, R., Shoop, R., \& Schunn, C. D. (2015). Case studies of a robot-based game to shape interests and hone proportional reasoning skills. International Journal of STEM Education, 2(1), 4-16.

Alimisis, D. (2013). Educational robotics: Open questions and new challenges. Themes in Science \& Technology Education, 6(1), 63-71.

Atasoy, E. ve Bulut, D. B. (2018). Lise 4. sınıf öğrencilerinin geometri konularındaki cebirsel düşünme süreçlerinin incelenmesi. Necatibey Eğitim Fakültesi Elektronik Fen ve Matematik Eğitimi Dergisi, 12(2), 199-227.

Barreto, F., \& Benitti, V. (2012). Exploring the educational potential of robotics in schools: A systematic review. Computers \& Education, 58(3), 978-988.

Bike-Kalkan, D. (2014). Sekizinci sınıf öğrencilerinin kavramsal anlama ve cebirsel muhakeme yapılar (Yayınlanmamış yüksek lisans tezi). Anadolu Üniversitesi, Eğitim Bilimleri Enstitüsü, Eskişehir.

Bruciati, A. P. (2004). Robotics technologies for K-8 educators: A semiotic approach for instructional design. Journal of Systemics, Cybernetics and Informatics, 2(1), 61-65.

Caci, B., Cardaci, M., \& Lund, H. H. (2003). Assessing educational robotics by the "Robot edutainment questionnaire” (Technical report). The Maersk Mc-Kinney Moller Institute for Production Technology, University of Southern Denmark.

Cobb, P. (2000). Conducting teaching experiment in collaboration with teachers. In A. E. Kelly \& R. A. Lesh (Eds.), Handbook of research design in mathematics and science education (pp. 307-333). London: Lawrence Erlbaum Associates Publishers.

Cobb, P., Confrey, J., Disessa, A., Lehrer, R., \& Schauble, L. (2003). Design experiments in educational research. Educational Researcher, 32(1), 9-13.

Çavaş, B., \& Çavaş-Huyugüzel, P. (2005,Şubat). Teknoloji tabanlı öğrenme: “Robotics club”. 7. Akadamik Bilişim Sempozyumu'nda sunulan bildiri, Gaziantep.

Çelik, D. (2007). Öğretmen adaylarının cebirsel düşünme becerilerinin analitik incelenmesi (Yayımlanmamış doktora tezi). Karadeniz Teknik Üniversitesi, Eğitim Bilimleri Enstitüsü, Trabzon.

Dinçer-Kucuş, B. ve Cantürk-Günhan, B. (2017, Mayıs). Eğitsel robotik uygulamalarının 7. sınıf öğrencilerin orantısal akıl yürütme becerilerine etkisi. 3. Türk Bilgisayar ve Matematik Eğitimi Sempozyumu'nda sunulan bildiri, Afyon.

Dindyal, J. (2004). Algebraic thinking in geometry at high school level: Students' use of variables and unknowns. In I. Putt, R. Faragher \& M. McLean (Eds.), Proceedings of the 27th Annual Conference of the Mathematics Education Group of Australasia (pp.183-190). Townsville: MERGA. 
Driscoll, M. (1999). Fostering algebraic thinking: A guide for teachers, grades 6-10. Heinemann: Portsmouth.

Eguchi, A. (2010). What is educational robotics? Theories behind it and practical implementation. In D. Gibson \& B. Dodge (Eds.), Proceedings of Society for Information Technology \& Teacher Education International Conference 2010 (pp. 4006-4014). USA: Association for the Advancement of Computing in Education.

Erdem, E. (2011). Illköğretim yedinci sınıf ögrencilerinin matematiksel ve olasılıksal muhakeme becerilerinin incelenmesi (Yayımlanmamış yüksek lisans tezi). Adıyaman Üniversitesi, Fen Bilimleri Enstitüsü, Adiyaman.

Freeman, A., Adams-Becker, S., Cummins, M., Davis, A., \& Hall Giesinger, C. (2017). NMC horizon report: 2017 higher education edition. Texas: The New Media Consortium.

Gennari, R., Dodero, G., \& Janes, A. (2012, April). Junior university workshops for children. Paper presented at the meeting of proceedings of 3rd international workshop teaching robotics, teaching with robotics integrating robotics in school curriculum riva del garda. Trento, Italy.

Gerecke, U., \& Wagner, B. (2007). The challenges and benefits of using robots in higher education. Intelligent Automation and Soft Computing, 13(1), 29-43.

Goldman, R., Eguchi, A., \& Sklar, E. (2004). Using educational robotics to engage inner-city students with technology. In Y., B. Kafai, W. A. Sandoval \& N. Enyedy (Eds.) Proceedings of the 6th International Conference on Learning Sciences (pp. 214-221). Santa Monica, California: Lawrence Erlbaum Associates.

Göksoy, S. ve Yılmaz, İ. (2018). Bilişim teknolojileri öğretmenleri ve öğrencilerinin robotik ve kodlama dersine ilişkin görüşleri. Düzce Üniversitesi Sosyal Bilimler Enstitüsü Dergisi, 8(1), 178-196.

Greenes, C., \& Findell, C. (1998). Groundworks: Algebra puzzles and problems (Grades 4, 5, 6 and 7). Chicago: Creative Publications.

Gürbüz, R. ve Şahin, S. (2015). 8. sınıf öğrencilerinin çoklu temsiller arasındaki geçiş becerileri. Kastamonu Eğitim Dergisi, 23(4), 1869-1888.

Herbert, K., \& Brown, R. (1997). Patterns as tools for algebraic reasoning. Teaching Children Mathematics, 3, $340-345$

Hoff, E. (2006). How social contexts support and shape language development. Developmental Review, 26(1), 55-88.

Jimoyiannis, A., \& Komis, V. (2001). Computer simulations in physics teaching and learning: A case study on students' understanding of trajectory motion. Computer and Education, 36, 183-204.

Johnson, J. (2003, January). Children, robotics and education. Paper presented at the meeting of proceedings of 7 th international symposium on artificial life and robotics. Oita, Japan.

Kabael, T. ve Ata-Baran, A. (2016). Matematik öğretmenlerinin matematiksel iletişim becerilerinin gelişimine yönelik farkındalıklarının incelenmesi. İlköğretim Online, 15(3), 868-881.

Kaf, Y. (2007). Matematikte model kullanımının 6. sınıf ögrencilerinin cebir erişilerine etkisi (Yayımlanmamış yüksek lisans tezi). Hacettepe Üniversitesi, Eğitim Bilimleri Enstitüsü, Ankara.

Kaput, J. J. (1999). Teaching and learning a new algebra. In E. Fennema \& T. A. Romberg (Eds.), Mathematics classrooms that promote understanding (pp. 133-155). Mahwah, NJ: Erlbaum.

Karsan-Erbaş, S. (2014). Temel robotik uygulamalar ve bilgisayar destekli tasarım eğitimindeki yeri. Eğitim ve Ögretim Araştırmaları Dergisi, 3(3), 304-312.

Kasmer, L. (2008). The role of prediction in teaching and learning of algebra (Unpublished doctoral dissertation). Western Michigan University, Kalamazoo, the USA.

Kaya, D. ve Keşan, C. (2014). İlköğretim seviyesindeki öğrenciler için cebirsel düşünme ve cebirsel muhakeme becerisinin önemi. International Journal of New Trends in Arts, Sports \& Science Education (IJTASE), 3(2), 38-48.

Kıran, B. (2018). Üstün yetenekli ortaokul öğrencilerinin proje tabanll temel robotik eğitim süreçlerindeki yaratıcı, yansıtıcı düşünme ve problem çözme becerilerine ilişkin davranışlarının ve görüşlerinin incelenmesi (Yayımlanmamış yüksek lisans tezi). Başkent Üniversitesi, Eğitim Bilimleri Enstitüsü, Ankara.

Kieran, C., \& Chalouh, L. (1993). Prealgebra: The transition from arithmetic to algebra. In D. T. Owens (Ed.), Research ideas for the classroom: Middle grades mathematics (pp. 179-198). New York: Macmillan.

Knuth, E. J. (2000). Understanding connections between equations and graphs. The Mathematics Teacher, 93(1), 48-53.

Koç-Şenol, A. ve Büyük, U. (2015). Robotik destekli fen ve teknoloji laboratuvar uygulamaları: Robolab. Turkish Studies, 10(3), 213-236.

Küçük, S. ve Şişman, B. (2017). Birebir robotik öğretiminde öğreticilerin deneyimleri. Ilkogretim Online, 16(1), 312-325.

Lempp, H., \& Kingsley, G. (2007). Qualitative assessments. Best Practice \& Research Clinical Rheumatology, 21(5), 857-869.

Lesh, R., \& Kelly, A., (2000). Multitiered teaching experiments. In A. Kelly \& R. Lesh (Eds.), Research Design in Mathematics and Science Education (pp. 197-230). Mahwah, New Jersey: Lawrence Erlbaum Associates.

Lin, C., Liu, E. Z., Kou, C., Virnes, M., Sutinen, E., \& Cheng, S. S. (2009). A case analysis of creative spiral instruction model and students' creative problem solving performance in a Lego ${ }^{\circledR}$ robotics course. In Chang, 
M., Kuo, R., Kinshuk, Chen, G. D., Hirose M. (Eds.), Edutainment 2009 (pp. 501-505). Heidelberg: Springer.

Liu, E. Z. H., Lin, C. H., Feng, H. C., \& Hou, H. T. (2013). An analysis of teacher-student interaction patterns in a robotics course for kindergarten children: A pilot study. The Turkish Online Journal of Educational Technology, 12(1), 9-18.

Milli Ĕ̆itim Bakanlığ1 [MEB]. (2018). Illkögretim matematik dersi ögretim programı (ilkokul ve ortaokul 1, 2, 3, 4, 5, 6, 7 ve 8. sınıflar). Ankara: Milli Eğitim Bakanlığ 1 Talim ve Terbiye Kurulu Başkanlığı.

National Council of Teachers of Mathematics [NCTM]. (2000). Principles and standards for school mathematics. Reston, VA: NCTM.

Nilklad, L. (2004). College algebra students' understanding and algebraic thinking and reasoning with functions (Unpublished doctoral dissertation). Oregon State University, the USA.

Organisation for Economic Co-operation and Development [OECD]. (2013). "PISA 2012 assessment and analytical framework: Mathematics, reading, science, problem solving and financial literacy." Retrieved June 28, $2020 \quad$ from https://www.oecdilibrary.org/docserver/9789264190511en.pdf?expires=1593346108\&id=id\&accname=ocid53022151\&checks um=10529135E50AC4E330347792E18241BA

Papert, S. (1972). Teaching children thinking. Innovations in Education and Training International, 9(5), pp. 245-255.

Papert, S. (1993). Mindstorms: Children, computers, and powerful ideas (2nd ed.). New York, NY: Basic Books.

Pellegini, A. D., Galda, L., Flor, D., Bartini, M., \& Charak, D. (1997). Close relationships, individual differences, and early literacy learning. Journal of Experimental Child Psychology, 67, 409-422.

Pritchard, A., \& Woollard, J. (2010). Psychology for the classroom: Constructivism and social learning. London and New York: Routledge.

Ribeiro, C. (2006). RobôCarochinha:Um estudo qualitativo sobre a robótica educativa no $1^{\circ}$ ciclo do ensino básico [RobôCarochinha: A qualitative study on educational robotics in the 1st cycle of basic education] (Unpublished master's thesis). Universidade do Minho, Braga.

Silik, Y. (2016). Ĕgitsel robotik uygulamalarının fen bilgisi ögretmen adaylarının problem çözme becerilerine etkisi (Yayımlanmamış yüksek lisans tezi). Karadeniz Teknik Üniversitesi, Eğitim Bilimleri Enstitüsü, Trabzon.

Steffe, L. P., \& Thompson, P. (2000). Teaching experiment methodology: Underlying principles and essential elements. In A. Kelly \& R. Lesh (Eds.), Handbook of research design in mathematics and science education (pp. 267 - 306). Mahwah, NJ: Lawrence Erlbaum Associates.

Steffe, L. P. (1991). The constructivist teaching experiment: Illustrations and implications. In E. Von Glasersfeld (Ed.), Radical constructivism in mathematics education (pp. 177-194). New York: Kluwer Academic Publishers.

Şişman, B. ve Küçük, S. (2018). Ortaokul öğrencilerine yönelik türkçe robotik tutum ölçeğinin geçerlik ve güvenirlik çalışması. Ege Eğitim Dergisi, 19(1), 284-299.

Talim ve Terbiye Kurulu Başkanlığı [TTKB]. (2006a). Illköğretim fen ve teknoloji dersi (6,7 ve 8. sinıflar) ögretim programı. Ankara: Yazar.

Talim ve Terbiye Kurulu Başkanlığ̣ [TTKB]. (2006b). Illköğretim teknoloji ve tasarım dersi ögretim programı ve kılavuzu (6, 7 ve 8. siniflar). Ankara: Yazar.

Talim ve Terbiye Kurulu Başkanlığı [TTKB]. (2009). Illköğretim matematik dersi 1-5. sinıflar ögretim programı. Ankara: Yazar.

Tekay, T. ve Doğan, M. (2015). İlköğretim 7. sınıf öğrencilerinin doğrusal denklemlerin grafikleri ile ilgili soruları çözme becerilerinin değerlendirilmesi. MATDER Matematik Ĕgitimi Dergisi, 2(1), 1-10.

Topping, K. J., Peter, C., Stephen, P., \& Whale, M. (2004). Cross-age peer tutoring of science in the primary school: Influence on scientific language and thinking. Educational Psychology, 24(1), 57-75.

Umay, A. (2003). Matematiksel muhakeme yeteneği. Hacettepe Üniversitesi Eğitim Fakültesi Dergisi, 24, 234243.

Uygun, T. ve Akyüz, D. (2019). Ortaokul matematik öğretmen adaylarının üçgen eşitsizliğini toplu argümantasyonla kavrayışları. İn̈nü Üniversitesi Eğitim Fakültesi Dergisi,, 20(1), 27-41.

Üçgül, M. (2013). History and educational potential of lego mindstorms NXT. Mersin Üniversitesi Eğitim Fakültesi Dergisi, 9(2), 127-137.

Üzümcü, Ö., ve Erdal, B. (2018). Eğitimde yeni 21. yüzyıl becerisi: Bilgi işlemsel düşünme. Uluslararası Türk Kültür Coğrafyasında Sosyal Bilimler Dergisi, 3(2), 1-16.

Vance, J. H. (1998). Number operations from an algebraic perspective. Teaching Children Mathematics, 4, 282285.

Williams, D., Ma, Y., Prejean, L., Lai, G., \& Ford, M. (2007). Acquisition of physics content knowledge and scientific inquiry skills in a robotics summer camp. Journal of Research on Technology in Education, 40(2), 201-216. 
Witherspoon, T., Reynolds, K., Copas, G., \& Alagic, M. (2004). A model for an online, global, constructionist learning environment: Robotics around the world. In R., Ferdig, C., Crawford, R. Carlsen, N. Davis, J., Price, R., Weber \& D., A., Willis (Eds.), Society for Information Technology \& Teacher Education International Conference (pp. 3083-3088). Waynesville, NC USA: Association for the Advancement of Computing in Education (AACE).

Wood, S. (2003, April). Robotics in the classroom: A teaching tool for $K$ - 12 educators. Paper presented at the Symposium of Growing up with Science and Technology in the 21st Century, Virginia, USA.

Yackel, E., \& Cobb, P. (1994, April). The development of young children's understanding of mathematical argumentation. Paper presented at the annual meeting of the American Educational Research Association, New Orleans, USA.

Yıldırım, A. ve Şimşek, H. (2005). Sosyal bilimlerde nitel araştırma yöntemleri (5. baskı). Ankara: Seçkin Yayıncilik.

Zengin, M. (2016). İlkokul, ortaokul ve lise öğrencilerin disiplinlerarası eğitim ve öğretiminde robotik sistemlerinin kullanımına yönelik görüşleri. Üstün Yetenekliler Eğitimi Araştırmaları Dergisi (UYAD), 4(2), 48-70. 